\title{
Unification of Archaeological Sites in Greece: A Design Approach Based on Public Participation and Sustainability Criteria
}

\author{
Kiriaki M. Keramitsoglou ${ }^{1,2}$, Efthymia M. Mylonopoulou2, Vasiliki I. Georgiou ${ }^{2}$, \\ Angelos L. Protopapas ${ }^{1,3}$, Konstantinos P. Tsagarakis ${ }^{2}$ \\ ${ }^{1}$ School of Science and Technology, Hellenic Open University, Patra, Greece \\ ${ }^{2}$ Department of Environmental Engineering, School of Engineering, Democritus University of Thrace, Business and \\ Environmental Technology Economics Lab, Xanthi, Greece \\ ${ }^{3}$ Department of Civil Engineering, School of Civil Engineering, Democritus University of Thrace, Xanthi, Greece \\ Email:johnkiki@hol.gr, aproto@civil.duth.gr,milonop@gmail.com,vgeorgiou@teemail.gr,kandila@her.forthnet.gr
}

How to cite this paper: Keramitsoglou, K. M., Mylonopoulou, E. M., Georgiou, V. I., Protopapas, A. L., \& Tsagarakis, K. P. (2017). Unification of Archaeological Sites in Greece: A Design Approach Based on Public Participation and Sustainability Criteria. Current Urban Studies, 5, 236-274.

https://doi.org/10.4236/cus.2017.52014

Received: March 13, 2017

Accepted: June 27, 2017

Published: June 30, 2017

Copyright $\odot 2017$ by authors and Scientific Research Publishing Inc. This work is licensed under the Creative Commons Attribution International License (CC BY 4.0).

http://creativecommons.org/licenses/by/4.0/

c) (†) Open Access

\begin{abstract}
The simultaneous involvement of aesthetic variables and economic, social and environmental objectives in urban design and planning is quite rare, and difficult to be implemented and interpreted within a local context. The top-down approach has been the most common strategy employed in urban planning, whereas sustainability principles call for more participatory methods. This study presents a design approach to the unification of archaeological sites in the town of Didimoticho, Greece, based on public participation and sustainability criteria. A fully structured questionnaire was used to define aesthetic parameters. Six options were designed and then evaluated by the local community. Thus, taking into account the local conditions, a list of Must and a list of Wants were established according to selected sustainability criteria, which are significant tools for the Kepner-Tregoe model application. The proposed methodology revealed the optimal design solution. This systemic participatory approach applicable to urban design and planning can be implemented in other cases as well.
\end{abstract}

\section{Keywords}

Genius Loci, Historic Landscapes, Multicriterion Model, Natural Landscapes, Pavement Design, Sustainable Planning

\section{Introduction}

Being an integral part of a place's natural and cultural heritage, landscapes play an important role at cultural, environmental, economic and social level. Climatic 
and environmental changes, rapid socio-economic growth, uncontrolled urbanization and globalization threaten and cause a rupture in the close relationship between a local community and its space (Antrop, 2005; Karpodini-Dimitriadis, 2009; Van Eetvelde \& Antrop, 2004). These developments gave rise to the need to conserve and protect the holistic and complex character of landscapes; as a result questions are raised in relation to the concept of sustainability such as what should be preserved and protected, at what level and what the time span should be. The response was given by the Convention of Florence (ELC, 2011), which except for the importance of sustainable development of tangible inherent qualities and values of landscapes such as natural resources, biodiversity, habitats, water and cultural heritage, introduced the importance of intangible values such as picturesqueness, aesthetics, identity and spirit of the place. The Convention essentially aimed to bridge past with future landscapes, but without any specific references to how this could be actually achieved (Antrop, 2000, 2005, 2006; ELC, 2011; Van Damme, Leinfelder, \& Uyttenhove, 2012; Von Haaren, 2002). This might pose a problem which local communities should resolve.

This problem has been expressed, especially at local level, by organized actions taken by the inhabitants of the town of Didimoticho, highlighting the need for planning studies and projects which would take into account the parameters that define the current role and interaction of the archaeological sites and monuments with the daily life of the town but also the inhabitants' need for quality public open spaces. This need led to the idea that the unification of archaeological sites would help their promotion, protection and involvement in everyday town life.

The aim of this paper is to put forward a proposal for the paving of the unification zone of the archaeological sites; the proposal is based on sustainability criteria and public participation in the design process and looks into the connection of two acropolises, Kales and Plotinopolis, with a street of 1600 meters in length, mostly running in parallel with the southern and south-eastern side of the castle "Kales" walls and the flow of the river Erythropotamos (Figure 1).

Two principal research problems had to be solved: the definition of aesthetic parameters and sustainability criteria in accordance with local conditions. Furthermore, given that 1) it is essential, yet difficult to understand aesthetic factors within a local context and therefore taking them into account in sustainable design is rarely the case (Anonymous, 2012; Dreiseitl, 2013; Meyer, 2008); 2) the top-down approach is the most common strategy employed when designing a public space (Anuar \& Saruwono, 2012; Hidle \& Leknes, 2012; Mahdavinejad \& Abedi, 2011), although literature on this issue argues that public participation in local planning is an ethical practice, which should be encouraged, taking into account local cultural conditions and the power structure of the local community (Arnstein, 1969; Baum, 1998; Friedmann, 1998; Rydin \& Pennington, 2000; Tauxe, 1995); and 3) integrating social, economic and environmental aims into planning simultaneously is difficult to be achieved in practice (Campbell, 1996; Echenique, Hargreaves, Mitchell, \& Namdeo, 2012). Our contribution is a case 


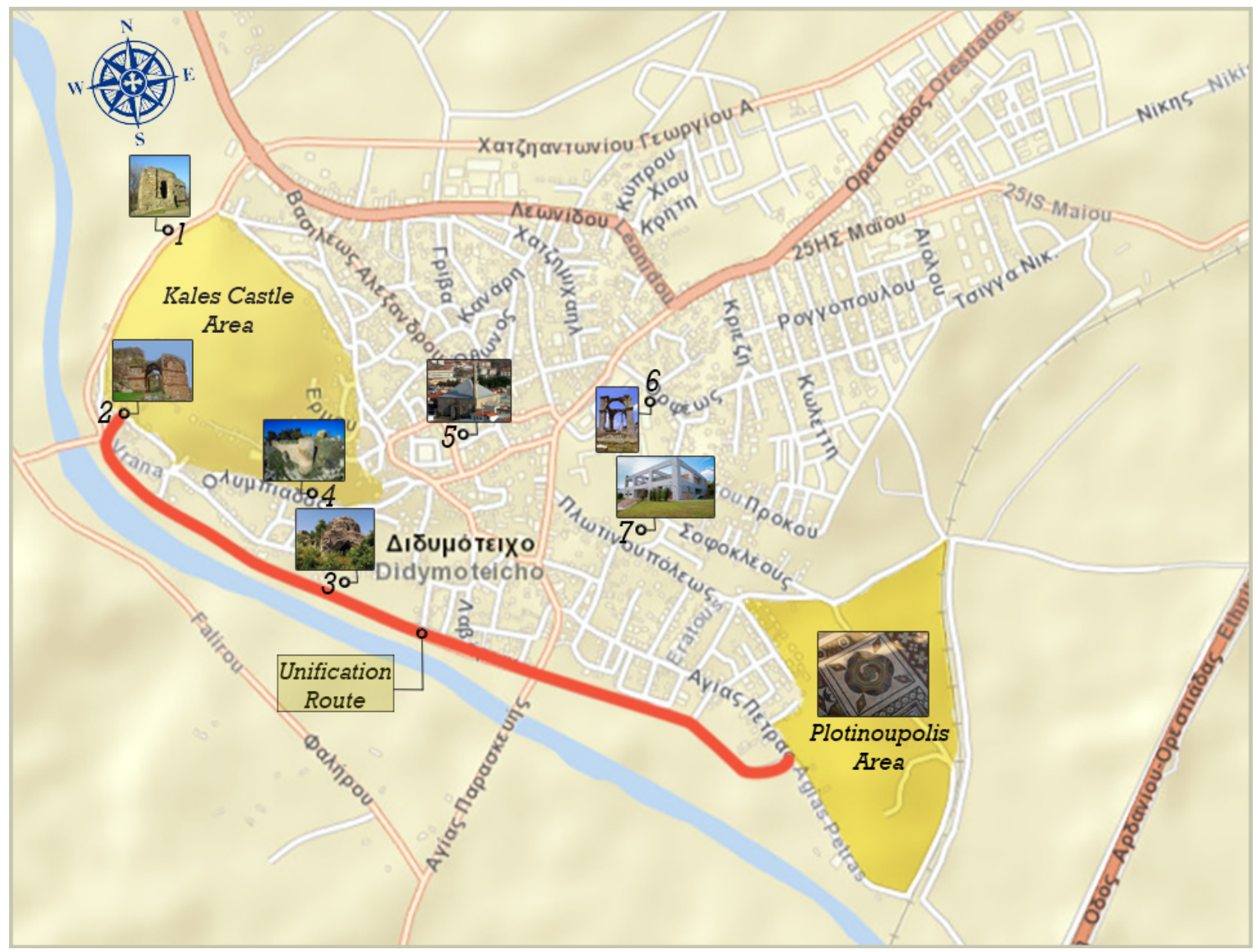

Figure 1. Kales Castle-Plotinopolis route; Monuments: 1. Pentazono, 2. Kalioportes Gates, 3. Ourouts Pasa's Baths, 4. the Tower of Princess, 5. the VagiazitMosque, 6. Pyrostia, 7. Byzantine Museum.

study that looks into the application of a participatory methodology which connects aesthetics and the three aforementioned dimensions of sustainability.

\subsection{Historic Landscapes and the Modern City}

Schulz was the first to introduce the term of genius loci, the spirit of place as perceived by people in a certain place and, defined the landscapes as romantic, cosmic, classic and complex according to their distinct characteristics structured by tangible and intangible forms (Schulz, 2009). Historic landscapes bear complicated features related to space and time. They reveal a unique "spirit of place" (genius loci) that shapes their identity. These particular landscapes and their monuments have a symbolic value and function as landmarks that allow orientation both in space and time. Monuments register a permanent, lasting trace in space, which keeps alive the thoughts and acts of those who built them, and create links between space and its people, and between history and memory. Monuments also establish the historical consistency of places. Changing their features and consistency would inevitably lead to loss of identity (Antrop, 2000; Kozyraki \& Tsalikidis, 2005; Stavridis, 2006). In light of the Nara Document of 
Authenticity, a broader understanding of the tangible and intangible values of the cultural heritage within the local context can assist practical decision-making in heritage conservation. Raising public awareness of the history and the meaning of the values represented by cultural properties themselves inspires public respect for the role monuments and historic sites play in contemporary society (ICOMOS, 1994).

However, inaccessible archaeological sites, silent monuments and the absence of daily interaction between modern space and people can lead to oblivion, wear and obsolescence. Management that tends to separate culture from nature and history from contemporary reality contributes significantly to the disintegration of the historic landscape and the gradual erasion of its identity; it further considers human beings only as passing visitors rather than as active participants (Kozyraki \& Tsalikidis, 2005). Therefore, any attempt to understand and protect historic landscapes should not only reconstruct past forms of the landscape, but also start with the contemporary environment and include local features, complexity and diversity of landscape to allow local communities to carry out their own assessment. Modern design of historic landscapes should be characterized by variability and adaptability so as to meet constant development and changes should highlight and preserve the natural and cultural diversity and uniqueness of the place; in other words, preserve the "spirit of place". Moreover, certain elements as topography, water, vegetation, climate, rocks and historical monuments are assessed by local residents and consequently design is based on how they understand their own place and how they intend to preserve or change it (Karpodini-Dimitriadis, 2009; Kozyraki \& Tsalikidis, 2005; Pellegrino, 2006; Stephenson, 2010). Recent research has shown that the participatory approach in design is a sustainable values-driven process and can be applied successfully (Echenique et al., 2012; Schilling \& Logan, 2008).

When designing interventions in historic landscapes, the challenge is obviously to address the creation of new elements of landscape which arise from the reality and diversity of the needs of contemporary human and other living beings; to integrate new design ideas, modern materials and new structures; or add new functions into existing ones, without subverting the identity of the landscape (Marcucci, 2000; Von Haaren, 2002). The unification of archaeological sites and thus of historic landscapes is a design proposal that aims to integrate them into modern city life, securing historical continuity and preserving the character of the city, while protecting and enhancing the landscapes by creating a unified network that apart from the dominant elements (monuments and places of historical memory) incorporates green and free public spaces, which could host cultural and leisure activities or facilities (Galani, 2004). The main connecting design element of such a network is a corridor which, being itself an outdoor public space, not only unifies historical and natural landscapes, but also connects people from different social groups, nationalities and ages with both their cultural past and future, thus promoting the sustainability of a "city system" (Fylaktou-Cattaneo, 2004; Gehl, 2002). 


\subsection{Principles, Criteria and Different Design Approaches to the Unification of Archaeological Sites}

Given the limited experience in unification of archaeological sites globally and the fact that according to the Convention of Florence (Prieur, 2006), the aesthetics, a dimension of the quality of landscapes, should be taken into account, the examination of two different design approaches followed in Athens, even though not participatory, provides significant input to understanding and defining aesthetic factors within a local context.

The creation of a network of pedestrian pathways that link the archaeological zones of Athens was part of one of the largest, unique and distinctive interventions aiming at the harmonious coexistence of various cultural elements associated with the city's historic heritage but also with its modern growth (Ministry-of-Culture-and-Sports, 2017). The "Athenian Walk", the main axis of the unification of the archaeological sites in Athens that connects downtown with the Acropolis, was made possible by turning Dionysios Areopagitis and Apostle Pavlos streets into pedestrian lanes (a total of 1700 meters in length). The paving of the pathways is compatible with the historic landscape, the Acropolis and the hills they connect but also with the surrounding urban environment. The austere paving, with its consistent and uniform appearance, without any inlays and morphological concoctions, restores a sense of continuity. The materials, gneiss cobblestone, whitish marble slabs, old curbs and gravel reinforced with cement, are also simple. The creation of links between civil and environmental options such as restoration, renewal, recycling and regeneration of urban infrastructure elements, the placement of appropriate lighting, the planting of trees and shrubs, along with the conservation and emergence of the historic olive grove, served the sustainability purposes well. Quality of life was improved by maintaining and increasing the green space, reducing air pollution, aesthetic upgrading, improving and encouraging the movement of pedestrians, restoring the continuity of public and historical sites, and securing easy access to open spaces by public transport (Fylaktou-Cattaneo, 2004; Loukaki, 2008; Papageorgiou-Venetas, 2005; Ministry-of-Culture-and-Sports, 2017).

Half a century ago, the renowned architect Dimitris Pikionis, the forerunner of the unification of the archaeological sites, created two spiral paths, one closing at the site of the Acropolis hill, while the other moved away from the Acropolis, towards the Filopappos hill, leading to a plateau where walkers can have a view of the sacred rock of the Acropolis. Because of the sequence of design and various improvised events fabricated into a meaningful coherent unit, this route has been described as a narrative route, in contrast to the simple and uniform character of the "Athenian Walk". The sustainable design served its purpose well, even though the concept of the project implementation was unknown at the time (1954-1958). The configuration of paths and the interventions are in perfect harmony with the natural and historic landscape, a result of an in-depth awareness of the history of the place and its natural terrain. Pikionis "listened" to the "spirit of place" and promoted its uniqueness through diversity (Iliakis, 2011; 
Kathimerini, 1994). The work looks for common elements between the global tradition (antiquity, eastern culture, modernism) and the Greek tradition. The character of paving changes depends on visual escapes to the monuments. The paving at the Acropolis makes constant references to antiquity, following more stringent geometric shapes; there is a clear reference to Byzantine tradition around the church of St. Demetrios Loumpardiaris on the Filopappos hill, while the southern part of the hill walk is influenced by the modern city. The alternation of visual perceptions is continuous and the element of surprise constantly plays an important role. The motifs of paving become more frequent and more complex in steep paths so as to entertain the walker's spirit, helping him climb. Paving surrounds trees and shrubs and avoids rocks, turning the walker's attention to natural elements. The kerbs where rain water flows, help rain become a narrative event that accompanies the walker on his track and has connotations of nature similar to the eastern Japanese tradition; Pikionis was familiar with the latter, which to some extent is similar to the perception of nature and space ancient Greeks held (Iliakis, 2011; Kapsali \& Potiriadi, 2010). The global and local identity of monuments is bridged with references to modernism (paintings of Paul Klee) and influences from cubism (Picasso and Braque). The history of place and myths interact with the scenery and the modern city. The connection to the modern is achieved with the use of concrete and brick with holes, while the connection to tradition is accomplished with the reuse of materials derived from the mass demolitions of neoclassical buildings and Athenian houses of this particular era; ancient clay, marble or stone findings are also used. The substratum of paving, a layer of sand, $25 \mathrm{~cm}$ thick, allows the rainwater to be filtered towards the underground aquifer. The massive lime stones alternate with thick marble slabs of various shapes and sizes and in between them, stripes of concrete lie. The walk turns into a spiritual experience, activating the presence of walker with inventions associated with selected visual escapes to the landscape and allowing the natural elements to emerge. The inseparable blending of nature with history has been achieved by combining local and universal elements (Iliakis, 2011; Kapsali \& Potiriadi, 2010; Kathimerini, 1994; Kotionis, 2004; Loukaki, 2008).

\subsection{The Case Study}

Built on the confluence of the major river Evros and its tributary Erythropotamos, Didimoticho is a provincial town located in the north-eastern Greece; its population comes to 9367 inhabitants (2011 census). Its history goes back to prehistoric and ancient times while many monuments from the Roman, Byzantine and Ottoman Empire eras are preserved (Figure S1). Various ethnic groups, Gypsies, Turks, Armenians and Jews have lived in the town along with its main Greek population since the beginning of its history, creating a multicultural society. Most Turks fled as refugees to Turkey during the Balkan wars (1912-1913) and today the only Muslim residents of the town are the Roma who draw their origins from Egypt or the West Indies. Its Jewish community was one of the oldest in Greece and the largest in Greek Thrace. On May 4, 1943, in the midst 
of the German Occupation, 731 Jews were arrested and deported from Didimoticho to Poland, on a journey with no return. In the second half of the 19th century, its Armenian community experienced great social and economic development; the Armenians worked as silversmiths and traders. Today only a few Armenian families still live in the town. Ecosystems of rich biodiversity are found on the wetlands of the river network; today these ecosystems are threatened by intensive agriculture, excavations, soil extractions and illegal dumping of sewage and waste. The climate is Mediterranean with medium rainfall throughout the year, hot dry summers and wet cold winters accompanied by frequent snowfalls. In the absence of natural barriers, the region is exposed to northern winter winds but also to winds blowing from all directions throughout the year (Gouridis, 2006; Pantsoglou, 2006; Matzarakis, 2006; TET, 2011).

Thrace is a rural region and one of the most disadvantageous regions in Europe with a low level of economic and social development and a high rate of unemployment. Sustainable tourism ensuring the preservation of natural and cultural heritage could play a key role in the development of this rural region. Yet, this requires the creation of an appropriate infrastructure (Eurostat, 2013; Martín, Molina, \& Fernández, 2012).

According to the statute of the association "Kalioportes" founded in 2008 by the residents of the town's oldest neighbourhood, extended between the southern and south-eastern side of the "Kales" castle walls and the river Erythropotamos, one of its objectives is to promote the redevelopment of the riverside area. In order to communicate this need, the association organized the conference "Rivers within the cities; a blessing or a curse?" The participants in this open discussion suggested a pedestrian and cycling path be constructed, which would run along the riverside and Plotinopolis, and go around the town; the fragile river ecosystem and the natural landscape be protected, and the town's archaeological sites be promoted (Kalioportes, 2008, 2009). A group of young people started the "RedRiver festival" aiming at the promotion of the historical and natural features of the riverside by organizing cultural events (Figure S2); the festival has been held every year since 2008 ( $\dot{\lambda} \xi \alpha \tau \varepsilon, 2013)$. Another citizens' movement, the volunteer tourist guides, was initiated in 2007, in order to contribute to the promotion, rescue and preservation of the town's monuments and archaeological sites (Sinapidis, 2007a). Furthermore, an online article has been published to support the need of unification of the town's historic sites (Sinapidis, 2007b). In February 2014, an association of volunteer citizens "Kastropolites Knowledge \& Action" was established with the aim of promoting and raising public awareness of local history and heritage. Their latest venture was to uproot the weeds and clean the castle (Kastropolites, 2014).

On the one hand, the aforementioned actions of the town residents related to the need of both safeguarding and upgrading the town's historic and natural landscapes; on the other hand, the traffic problems caused by the narrow streets of the historic centre, lack of parking lots and the pedestrianization of the main commercial street without prior meticulous planning (Patsuridis, 2014; Sinapi- 
dis, 2006) made us have our research focused on the sustainable design of a pavement along the river as the best option for unifying the archaeological sites, namely the Roman town "Plotinopolis" and the "Kales" castle. Therefore, we excluded from our research the examination of alternative routes towards the interior part of the town, for instance, towards the Mosque which is located in the central square of the town and the new Byzantine museum, as such a study would require a wider multidisciplinary approach.

Under the administrative reform aiming at decentralization, the emperor Trajan (98 - 117 a.c.) established in honour of his wife Plotina, the town of Plotinopolis which grew into a commercial centre at the confluence of the rivers Erythopotamos and Evros, navigable in antiquity. The excavation research revealed impressive mosaics, ceramics, a pipeline system and coins, a complex of well and chamber of great architectural art and other findings which indicated that the citadel was populated from the 2nd until the 6th century a.c. (Figure S3). There is an ongoing excavation and the site is at the moment inaccessible to the public because of the lack of special housing which would preserve and protect it (Koutsoumanis, 2005). The fortification of the town and the construction of the castle walls date back to the mid-6th century, during the times of the Byzantine emperor Justinian, when the devastation of Plotinopolis began. Contrary to Plotinopolis, the castle is within an accessible site, part of which is inhabited (Gouridis, 2007; Papadopoulos, 1990). Yet, the access is not easy because the street is very steep (Figure S4).

\subsection{Sustainability, Participatory and Multicriterion Approach to Urban Design and Planning}

Integrating landscape into town design and planning policies reinforces and meets the requirements of sustainability. The concept of sustainability relates to the continuity of environmental, economic, cultural and social aspects of a place (Déjeant-Pons, 2006). According to the UNECE Aarhus Convention and the European Landscape Convention (ELC), a sustainable future depends directly on public participation in decision-making (Prieur, 2006; UNECE, 1998). Thus, legal and ethical reasons enforce citizens to take part in urban design and planning at particular stages of development.

As a result, 1) public participation can be used as an effective tool for local people to identify how they perceive landscapes and express their preferences and needs; 2) it may also improve decision-making as local knowledge, ideas and different views could complement expert knowledge; 3) it takes into consideration local culture and history; 4) it may ensure transparency and increase trust and acceptability of the final result (Blackstock \& Richards, 2007; Conrad, Christie, \& Fazey, 2011; Davies, Selin, Gano, \& Pereira, 2012; Matsuoka \& Kaplan, 2008).

The bottom-up approach can function in line with sustainability considerations and the legal framework. Nevertheless, it is important to take into account some limitations and potential pitfalls: 1) it is difficult to reach consensus 
amongst all stakeholders; increasing participation does not automatically entail that power relations and conflicts within the boundaries of research are resolved; local people should be prepared for the participatory activities; 2) minorities and particularly the destitute might be excluded from the research and, only "key informants" might be used or the demands of the more powerful be legitimized; 3 ) future participants, who will be affected by the results, are excluded from decision-making; 4) lack of public understanding of the value of cultural heritage conservation could be a problem (Arnstein, 1969; Byrne, 1991; Innes \& Booher, 2004; Maier, 2001; Næss, 2001; Sanoff, 2008; Thomas, Chataway, \& Wuyts, 1998; Yung \& Chan, 2011).

In order to address the ineffectiveness of the participatory mechanisms and given the time frame and the fact that we represent no official local public or private agent which could undertake the organization of workshops, we used structured questionnaires and interviews, randomly collected, as participation actions at two stages of the research (Hassan, El Hefnawi, \& El Refaie, 2011). We employed a multicriterion decision-making method to analyze and assess different alternative scenarios. A weakness of the multicriterion method is that the final solution depends mostly on weighting criteria which have often been selected and assessed arbitrarily (Dulmin \& Mininno, 2003; Lahdelma, Salminen, \& Hokkanen, 2000). The accurate calculation of the weights selected according to local conditions along with the sensitivity analysis made an objective and unambiguous approach possible.

\section{Research Methodology}

\subsection{Exploratory Research}

The exploratory research aimed to identify the distinctive character of local landscapes as these were perceived by the town residents; in particular, it looked into the relationship of space and time through the collective and individual memory, and the interaction between people and historical and natural landscapes. Exploring how local people determined the aesthetic parameters of the unification proposals was our main concern. Figure 2 presents the methodology process of the exploratory and main research we explain in detail in this section and in Appendices A-C.

For the purposes of our research, a questionnaire was designed comprising four parts. The first part consisted of a series of structured questions, investigating the level of information of respondents about the history of local monuments, the oral tradition through their knowledge of legends, and the assessment of the present condition and image of the town's archaeological sites. The option of a categorical response was given, ranking from "Most important" to "Least important". The questions of the second part were related to the level of respondents' information about the biodiversity of the network of the Erythropotamos and Evros rivers, their assessment of the current condition and image of the natural landscape, and of the degree of significance of values connected with the landscapes (Ode, Tveit, \& Fry, 2008; Tveit, Ode, \& Fry, 2006). The third part 


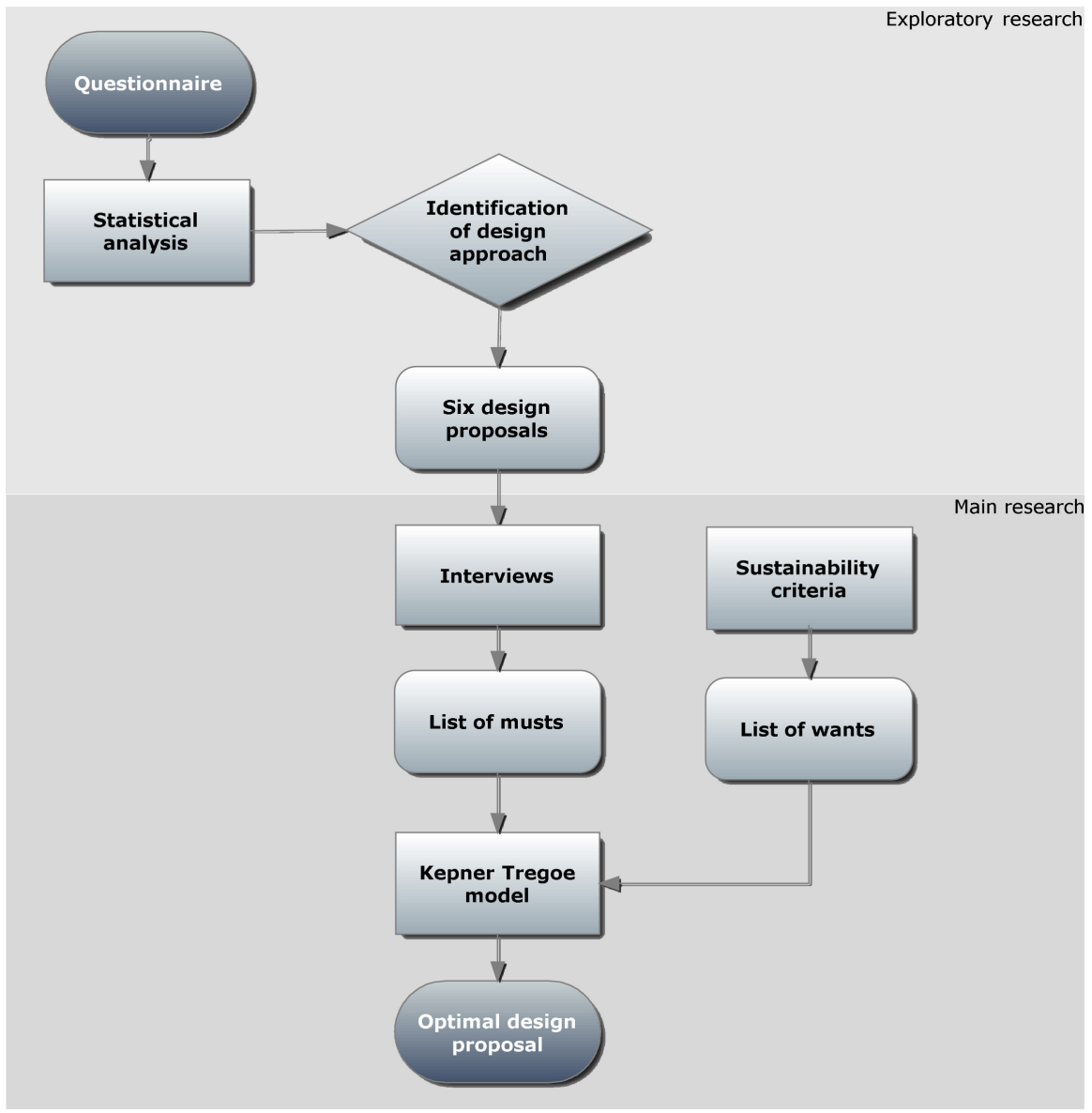

Figure 2. Research strategy.

aimed at eliciting the respondents' perception of the spirit of place and the principles and design approach they approved of with regard to the unification route. Finally, the fourth part included questions about the respondents' socio-economic background.

Concerning the aesthetic parameters related to the design of the unification pavement, the residents' preferences were explored using an interval scale for eight parameters:

"Austere-Complicated"

"With straight formations-With curved formations"

"With few colours-With many colours"

"Symmetric-Asymmetric"

"With smooth texture-With rough texture"

"With motifs-Without motifs"

"With similar materials-With different materials" and

"With contrasts-Unvaried"

They ranged from " -3 " to " +3 "; " 0 " indicated indifference. The questionnaire was pilot- tested before being finalized. Therefore, we tested the design principles followed such as a clear understanding of the objective of information requested by the respondents, neutrality, clarity and simplicity in the wording of 
questions and shortness, about ten minutes required time for filling up.

For the preliminary approach, two target groups were selected at random by two interviewers: adults aged 20 and above (Mean age $=47.41, S D=15.951$ ), and youths aged between 14 and 19 years (Mean age $=16.76, S D=1.041$ ) in accordance with the requirements of the European Landscape Convention, which emphasizes the role that young people could play in preserving landscape identity (E.C., 2006). About four out of five citizens accepted to participate in the survey. A total of 124 valid questionnaires were compiled; 50 of them were completed by adolescents. Participants completed the questionnaire in cafés, shops, open air markets, streets and outside the premises of the town's two secondary schools. Data was analyzed using the Statistical Package for the Social Sciences (SPSS13.0). Based on the design guidelines defined by the people of the initial survey, a sample of six alternative paving projects was designed with the use of the Computer Aided Design (AutoCAD) programme (Figure A1).

\subsection{The Main Research}

The aim of the main research was to explore reactions to "What if" scenarios, establishing a list of Musts and a list of Wants, which are significant tools for the application of the Kepner-Tregoe model depicted in Figure 2. This model is a simple multicriterion model suitable for comparing a limited number of different options, which are evaluated against a combination of Musts and Wants.

In this case, the model was used to evaluate the six unification options put forward by the preliminary research. The six design proposals were printed and then, evaluated by 61 residents (Mean age $=44.08, S D=17.373$ ) during personal interviews; they were given a score on a scale of 1 to 6 . In this way, the list of Musts was established. The number of options was considered neither small to restrict the number of choices nor large to cause confusion and difficulties in the assessment carried out by the participants. Our fieldwork showed that a higher number of printed solutions would be hardly manageable by both respondents and researchers.

Taking into account the local conditions such as climate and natural resources, five criteria of sustainability were determined and then a list of Wants weighed in the range 0 - 1 was established (Appendix B). Finally, the application of the model revealed the design proposal that best met the predetermined sustainability criteria.

\section{Data analysis and Results}

\subsection{Public Participation in the Design Approach}

Fifty four percent of the respondents preferred the path unifying the two acropolises to be used only by pedestrians and cyclists (33.1\%) rather than turned into a low traffic road (22.6\%), while $51.6 \%$ preferred a frieze of greenery to separate the different road services. $16.9 \%$ of the respondents described the landscape as romantic characterized by diversity and plurality. $7.3 \%$ described it as cosmic characterized by uniformity and geometry. $33.1 \%$ described it as classic 
characterized by harmonious balance, without plurality or monotony, which is unique in integrating distinctive elements and maintaining their identity on the whole. Finally, $42.7 \%$ described it as compound and complex with elements from all the aforementioned characterizations.

As to the definition of aesthetic variables and the character of paving, graphs in Figure 3 were created based on the responses of 124 participants. Concerning the "Austere-Complicated" choices, the most frequent responses occurred at the left hand, at the Austere panel of Figure 3(a) $(M=-1.000, S D=1.653)$. Concerning the "With straight formations" to "With curved formations" choices (Figure 3(b)), there was a significant peak at the value 0 ; in this case, the low standard deviation shows that the data points tend to be very close to the mean $(M=-0.161, S D=1.605)$. Concerning the "With few colours" to "With many colours" choices (Figure 3(c)), more responses occurred at the left panel ( $M=$ $-0.331, S D=1.966)$ and the same happened with the "Symmetric" to "Asymmetric" choices presented in Figure 3(d) $(M=-0.234, S D=1.673)$, while the mean value was closer to the right hand panel of "With smooth-rough texture" choices (Figure 3(e)), to the rough texture panel $(M=0.250, S D=2.019)$. The responses were shared almost equally left and right of the mean highest value to the "With motifs-Without motifs" panels in Figure 3(f) $(M=-0.024, S D=2.001)$ and the same was observed with the "With similar-With different materials" choices of Figure 3(g) $(M=-0.105, S D=2.019)$. Finally, the most frequent responses occurred at the right hand at the "Unvaried" panel in Figure 3(h), concerning the "With contrasts-Unvaried" choices $(M=0.508, S D=1.973)$.

\subsection{Analysis of Design Proposals}

Taking into account the local conditions and the analysis of data collected by the questionnaire at the preliminary stage (see Appendix A and Appendix C), six paving designs, presented in Figure A1, were developed. Then, local residents were requested to evaluate the six proposals by means of personal interviews.

The main idea was to design two paths, one for pedestrians and another for cyclists separated with a greenery frieze (Figure 4). The pedestrian path was paved with grey granite cobblestones and ran along the river, while the bicycle lane was constructed with packed soil. The greenery strip between the pedestrian and bicycle lane was demarcated with red brick.

\subsection{Identification of Musts and Wants}

The total scores (TS) of the design proposals were obtained by processing the data of the design proposals evaluation sheets ( 61 in total) filled in by the interviewees and the definition of a list of Musts $(\mathrm{M})$ on a hierarchical scale ranging from 1 to 6 was estimated with Equation (1) for each proposal.

$$
\operatorname{TSM}_{j}=\sum_{i=1}^{61} \bar{z}_{i j}
$$

where $z_{i j}$ is the score of respondent i for the jth case $(j=1,2, \cdots, 6)$. 


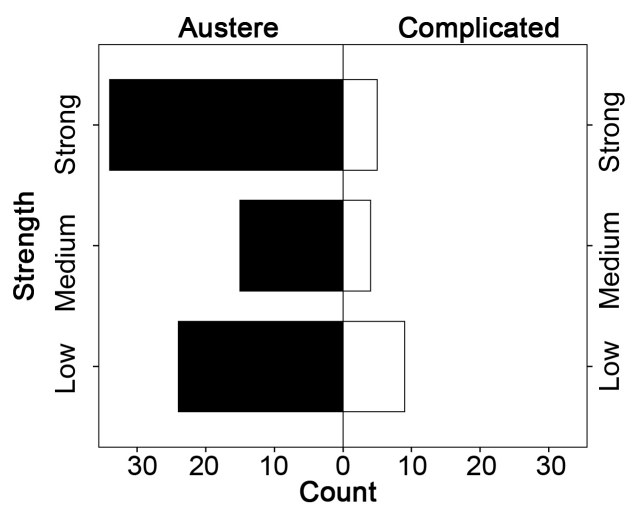

(a)

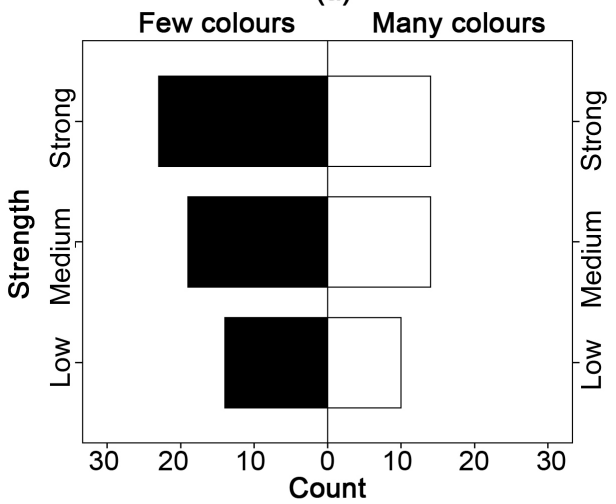

(c)

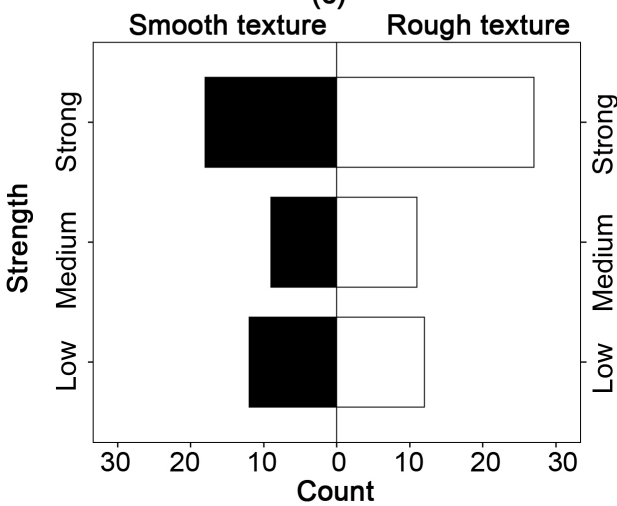

(e)

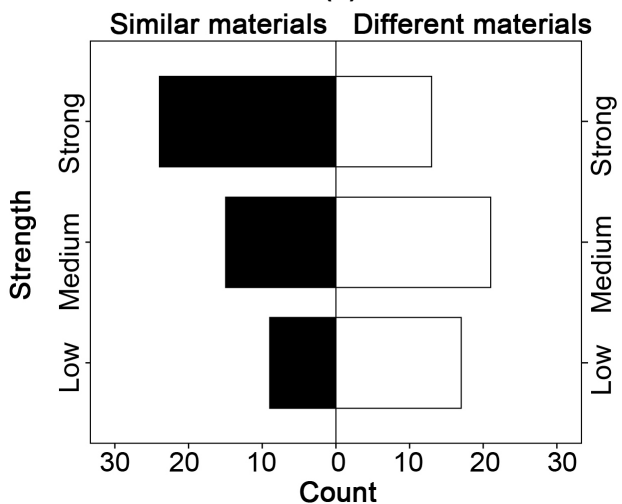

(g)

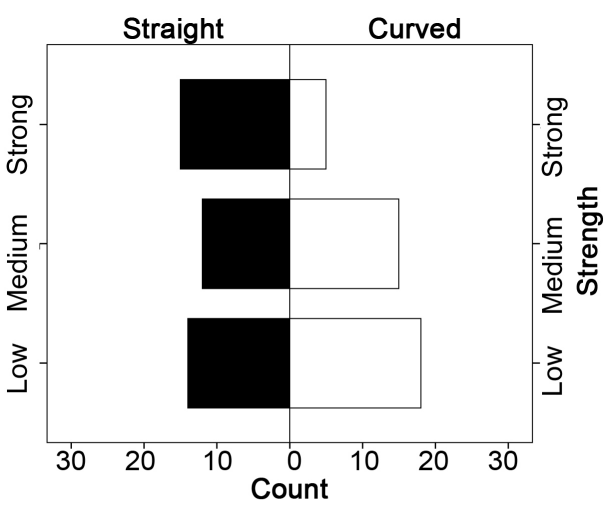

(b)
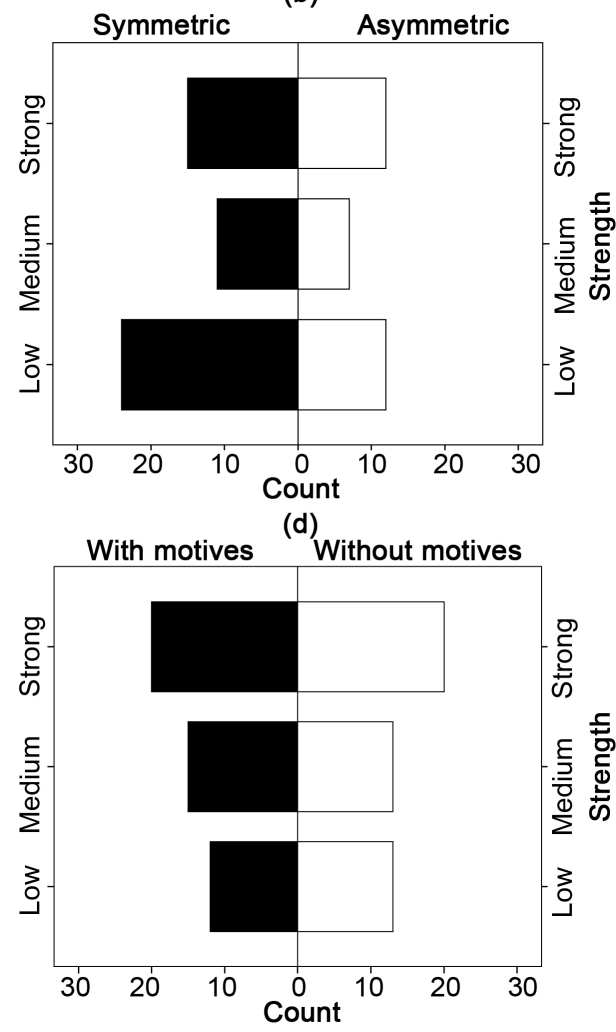

(f)

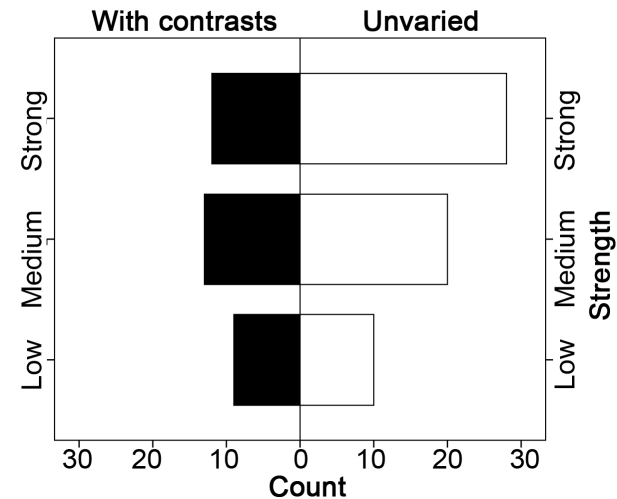

(h)

Figure 3. People's choices between $(N=124)$ : (a) Austere and complicated, (b) with straight and curved formations, (c) with few and many colours, (d) symmetric and asymmetric, (e) with smooth and rough texture, (f) with and without motifs, (g) with similar and different materials and $(\mathrm{h})$ with contrasts and unvaried. 


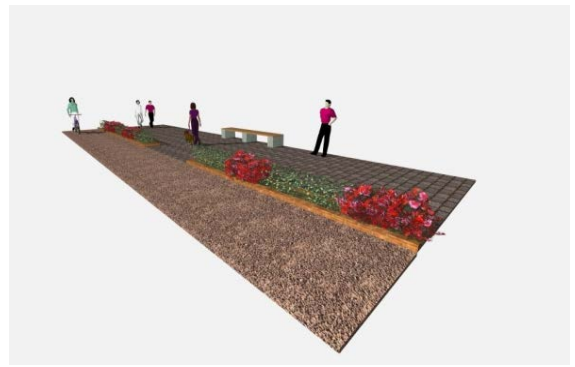

(a)

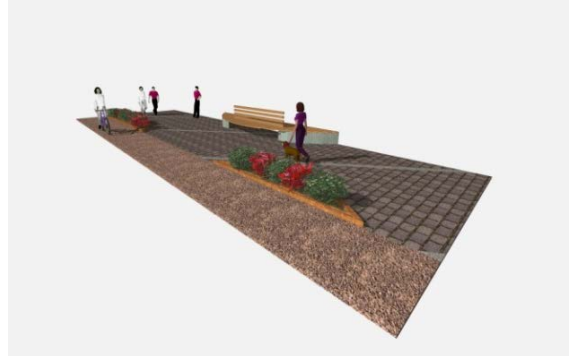

(c)

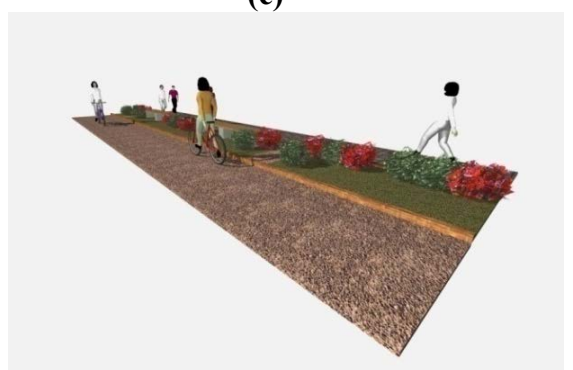

(e)

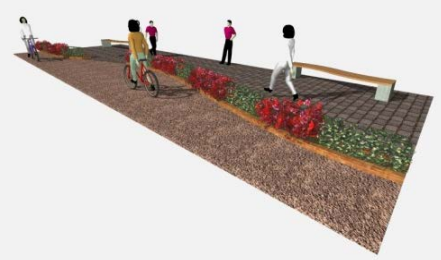

(b)

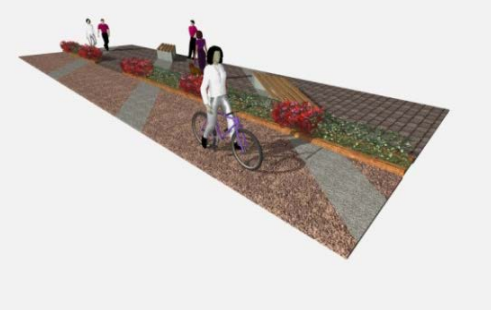

(d)

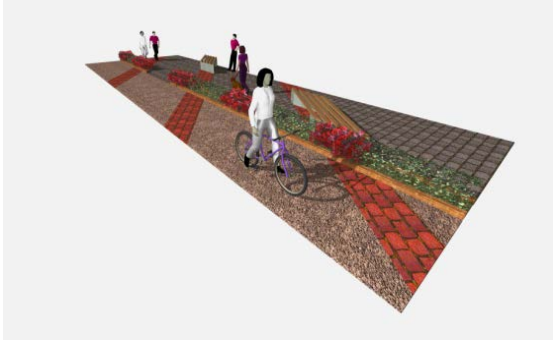

(f)

Figure 4. Snapshots of the design proposals: (a) first, (b) second, (c) third, (d) forth, (e) fifth and (f) sixth.

The detailed calculation of weight factors based on five sustainability criteria selected, i.e. construction cost, local availability of materials, embodied energy, albedo and permeability of the unit of $108 \mathrm{~m}^{2}$ of the six design proposals along with the justification for this choice is presented in more detail in Table 1 and Appendix B. The total scores (TS) of "Wants" (W) was estimated with Equation (2) for each proposal.

$$
\mathrm{TSW}_{j}=\sum_{c=1}^{5} x_{c j}
$$

where $x_{c j}$ is the score of the criterion $c(c=1,2, \cdots, 5)$ for the jth case $(j=1,2, \cdots, 6)$.

\subsection{The Application of Kepner-Tregoe Model}

For the application of Kepner-Tregoe model Musts and Wants must be multiplied as indicated by Equation (3) in order to calculate the final scores (FS). Calculations led to conclusion that the 5th proposal was the best option (Table 1).

$$
\mathrm{FS}_{j}=\mathrm{TSM}_{j} * \mathrm{TSW}_{j}
$$

A sensitivity analysis was undertaken for the weight of cost criterion ranging 
Table 1. Final results.

\begin{tabular}{ccccccc}
\hline $\begin{array}{c}\text { Design } \\
\text { Proposals (j) }\end{array}$ & TSM & $\begin{array}{c}\text { Residents' } \\
\text { choices rank }\end{array}$ & TSW & $\begin{array}{c}\text { Criteria } \\
\text { rank }\end{array}$ & FS & $\begin{array}{c}\text { Kepner-Tregoe } \\
\text { rank }\end{array}$ \\
\hline 1st & 3.344 & 4 & 2.105 & 4 & 7.040 & 5 \\
2nd & 3.787 & 2 & 2.124 & 3 & 8.042 & 2 \\
3rd & 3.393 & 3 & 2.087 & 5 & 7.083 & 4 \\
4th & 3.066 & 5 & 2.535 & 2 & 7.772 & 3 \\
5th & 4.803 & 1 & 3.169 & 1 & 15.223 & 1 \\
6th & 2.656 & 6 & 2.016 & 6 & 5.353 & 6 \\
\hline
\end{tabular}

from $0 \%$ to $100 \%$; the fifth proposal remained at the first rank for all examined weights. Moreover, the 5th proposal accumulated in total 293 points $\left[\left(2 \mathrm{X}_{1}\right)+\right.$ $\left.\left(2 \mathrm{X}_{2}\right)+\left(5 \mathrm{X}_{3}\right)+\left(15 \mathrm{X}_{4}\right)+\left(10 \mathrm{X}_{5}\right)+\left(27 \mathrm{X}_{6}\right)\right](M=4.803)$ and the Wilcoxon Signed Ranks test indicated to be leading with statistically significant difference from the second one $(M=3.787)$ and thus from all the rest $(z=-3.167, p=0.002)$.

\section{Discussion}

According to the data of the initial questionnaire survey, a high percentage of respondents stated that their knowledge of local history and biodiversity of the riparian zone was poor. More than $50 \%$ of them were somewhat informed about the meaning of the names of three out of seven places they had been asked about. Interestingly, a large percentage of respondents (72.6\%) did not know the meaning of the name of the "Pentazonon" monument located on the riverside, adjacent to a high traffic road, which took its name from the morphology of the monument, i.e. the alternation of five zones of bricks with stone blocks. However, most of the respondents had heard a legend, tradition or tale related to the town's history, which serves as evidence of a live collective memory. Besides, "the narratives are that make cultural heritage real to people" (Swensen, Jerpåsen, Sæter, \& Tveit, 2012). They also stated that they visit archaeological sites including those of their hometown, yet not that often. According to them, the main reason why they did not visit the sites was lack of time, followed by lack of interest; the fact that visiting the monuments required hard walking was an additional deterrent (see Appendix C). These findings indicate that 1) the residents' perception of landscapes might be assessed on the grounds of "aesthetic" value which relates to their visibility and distinctive presence in the town's fabric and in the living memories the monuments represent rather than to knowledge of local history and biodiversity (Deeben, Groenewoudt, Hallewas, \& Willems, 1999; Loures, Vargues, \& Horta, 2008); 2) the need for the town's landscapes to attract the residents' interest without competing with any other social interests. Tourist activity, apart from its contribution to local economy, could raise awareness of cultural and natural heritage among local community (Carbone, Oosterbeek, \& Costa, 2012); 3) the importance of designing a mea- 
ningful space where stories could be heard (Mehta, 2014; Sandercock, 2003). The design we propose could form part of a wider urban planning necessary for keeping heritage sites alive and for making them attractive and accessible, and part of the required infrastructure for sustainable tourism development.

As far as the factors of degradation of the town's historic sites and landscapes were concerned, they were all generally evaluated as important (see Tables C1, Tables C2). However, the respondents indicated as most important, the scattered trash, the generally poor condition of landscapes, the lack of signs, the limited restoration and maintenance of monuments, the limited access to archaeological sites, their safety and the wild vegetation. The presence of insects in summer was evaluated quite important, obviously because of the mosquito infested region; walking along the route of the unification zone of the archaeological sites was described as pleasant and not at all tedious. The implementation of an intervention requires not only financial resources but also political will and changes in values and attitudes. All residents are partly responsible for rubbish scattered everywhere and generally for the poor condition of the landscapes. According to (Liberatore, 1995): "putting into practice the idea of sustainable development requires an integration of political will, economic and technical resources, knowledge of natural and social processes and changes in social values and behaviours that is very difficult to achieve". Moreover, given the present conditions of the town's landscapes, a value-based approach for heritage conservation, which attempts to engage the local community in the conservation process on the basis of tangible values rather than intangible ones, might be the best strategy at a first stage. A public acceptable design for the unification of archaeological sites could facilitate the connection of local people with their heritage and help them to consider heritage as an integral part of their contemporary life and of a holistic view of the community development. Continuation of the past into future through the active role of the present community in landscape conservation and a living heritage approach which emphasizes intangible values would be the next step of an established value-based strategy (Abdel Tawab, 2012; Poulios, 2014).

All values associated with landscapes were important, most of all the intrinsic value of all creatures and biodiversity and least of all religion, meditation and contemplation. Entertainment with outdoor activities was evaluated more important than activities in the city (see Table C3). Previous research demonstrated that putting landscapes in the context of public perception could only be understood through the integration of values; consequently, their incorporation in planning is of crucial importance (de Groot, Winnubst, van Schie, \& van Ast, 2014; Mydland \& Grahn, 2011; Stephenson, 2008). Therefore, local people expressed their preference and need for clean, well-looked-after public spaces hosting social activities and humans, which would not be in conflict with wildlife and they stressed the importance of adopting parallel measures so as to protect natural habitats. This position was reinforced by the respondents' negative view of the presence of vehicles along the route of unification and their preference for a pedestrian-cycling route with a greenery frieze but also by their choice of the 
austere, simple design approach.

According to the evaluation of the respondents, the fifth proposal was well ahead of the rest (see Table 1). Apart from uniformity, symmetry, linearity and austerity, it was characterized by a greenery strip, 1.64 meters in width, with benches. The variety of plants of different texture, colour and shape could satisfy the preference of young people for complex and colourful paving (Appendix C) but also of those who selected asymmetry, curved shapes and motifs, enhanced by variability, which characterizes the water element and the form of torrential river.

As regards the evaluation of proposals in accordance with sustainability criteria, such as construction cost, local availability, albedo, embodied energy and permeability of materials used, results showed that the most expensive proposal was the sixth, followed by the third and the first ones, while the fifth was the cheapest. The surface of granite cobblestones, an expensive material, was the key factor that determined the cost (see Table B1, Table B7). The surface of cobblestones, material not locally available, also determined the assessment of proposals based on the second criterion. Thus, the fifth proposal got the highest score, followed by the fourth and second ones, while the sixth got the lowest (Table B2, Table B3, Table B7). The surface of greenery having low albedo determined the assessment rank for the third criterion and so the lowest score was obtained by the fifth proposal and the highest by the first, while the second and sixth ones got nearly the same points (see Table B4, Table B7). The fourth proposal embodied the most energy, followed by the third and sixth ones, while the fifth the less. The surfaces of gravel, material with high embodied energy and those of granite cobblestones determined the level of scoring, due to their heavy weight per unit area (see Table B5, Table B7). The fifth proposal was the most permeable, followed by the fourth because of the total size of greenery and gravel area, while the sixth was the least permeable due to the large surface paved with impervious granite (sees Table B6, Table B7).

After adjusting the points of all sustainability criteria, the fifth proposal received the highest score compared to the rest (see Table B8). This proposal proved to be the cheapest, with less embodied energy, easy to be constructed with locally available materials and planted with indigenous plants; it also had the highest permeability. This proposal had the lowest albedo; although summer temperatures in the region are very high, given that the route is in close proximity with the natural water, this could be considered less significant compared to a road in a completely urban environment.

To sum up, the present research indicated that 1) on a theoretical level, the participatory approach could be applied to an urban planning and design process which requires the definition and combination of aesthetic and sustainability factors; 2) on a practical level, a design proposal for the paving of the unification zone of archaeological sites in Didimoticho could be based on the spirit of place and local sustainability criteria. Moreover, it revealed the problems connected to the town's historical and natural landscapes. 


\section{Conclusion}

The design proposal of a pedestrian path paved with grey granite cobblestones and a cycling path paved with packed soil, separated from one another with a strip of greener, 1.64 meters in width, and benches, demarcated by red brick, in linear style following the curving patterns of the riverbed emerged as the most preferable solution for the unification of the archaeological sites of the town of Didimoticho. This proposal was evaluated with the highest scores by the residents among six proposals and, in addition, it also had the highest scores after making adjustments for construction cost, local availability, embodied energy, albedo and permeability of paving materials. It was also the most economical solution. This option also remained the optimal when weights were applied to the scores of "Wants" of five criteria. It was characterized by simplicity, geometric shapes, uniform and linear formations and could be constructed with the use of different, natural, mostly local materials. However, the austere design was moderated by diversity in texture, shape, colour and variability of plant species of the greenery frieze and the riparian zone due to seasonal changes. In addition, it could encourage walking and cycling and thus contact with nature and visiting archaeological sites, interpersonal contacts and meetings between people of all ages.

In particular, this survey clearly revealed the degraded image of the town's historical and natural landscapes; highlighted the need to preserve and restore the monuments, and undertake further excavation activities; also revealed the problem of the annoying presence of insects in summer, the poor knowledge of the inhabitants about their historical heritage and the biodiversity of the river network and the need for outdoor social and cultural activities.

Our research points out that the following issues require further investigation: 1) the regeneration of the riparian zone and the design of a pedestrian network which would connect the main suburban unification axis of archaeological sites with monuments located in the urban fabric, old traditional neighbourhoods and museums, 2) the study of planting and enrichment of the fauna of the riparian zone, 3) the creation of educational and informational material for all ages about the history and biodiversity of the region, 4) means to curb the mosquito problem and 5) the allocation of open spaces for hosting social and cultural activities.

In general, this study shed light on an applied methodology which could bear good results in practice; this methodology constitutes a useful tool not only for researchers but also for public authorities who wish to incorporate participatory and sustainability approaches to urban design and planning. Its academic significance consists in presenting the application of a model which simplifies and connects the complicated issues of aesthetics and sustainability concepts in a local urban context.

\section{References}

Abdel Tawab, A. G. (2012). Area-Based Conservation: The Strengths and Weaknesses of 
the Egyptian Emerging Experience in Area-Based Conservation. Alexandria Engineering Journal, 51, 137-152.

Anonymous (2012). Editorial Ethics/Aesthetics. Journal of Landscape Architecture, 7, 45.

Antrop, M. (2000). Background Concepts for Integrated Landscape Analysis. Agriculture, Ecosystems and Environment, 77, 17-28.

Antrop, M. (2005). Why Landscapes of the Past Are Important for the Future. Landscape and Urban Planning, 70, 21-34.

Antrop, M. (2006). Sustainable Landscapes: Contradiction, Fiction or Utopia? Landscape and Urban Planning, 75, 187-197.

Anuar, M. I. N. M., \& Saruwono, M. (2012). Barriers of User's Involvement in the Design Process of Public Parks as Perceived by Landscape Architects. Procedia-Social and Behavioral Sciences, 35, 253-259.

Arnstein, S. R. (1969). A Ladder of Citizen Participation. Journal of the American Institute of Planners, 35, 216-224. https://doi.org/10.1080/01944366908977225

Baum, H. S. (1998). Ethical Behavior Is Extraordinary Behavior; It's the Same as All Other Behavior: A Case Study in Community Planning. Journal of the American Planning Association, 64, 411-423. https://doi.org/10.1080/01944369808976001

Beckman, P. E., Dimoudi, A., Komnitsas, K., Kosmaki, P., Belavilas, N., \& Polizos, I. (2001). Bioclimatic Design and Planning of Buildings and Spaces (Vol. B, pp. 143-156). Patra: EAP (Hellenic Open University).

Blackstock, K. L., \& Richards, C. (2007). Evaluating Stakeholder Involvement in River Basin Planning: A Scottish Case Study. Water Policy, 9, 493-512.

https://doi.org/10.2166/wp.2007.018

Byrne, D. (1991). Western Hegemony in Archaeological Heritage Management. History and Anthropology, 5, 269-276. https://doi.org/10.1080/02757206.1991.9960815

Campbell, S. (1996). Green Cities, Growing Cities, Just Cities?: Urban Planning and the Contradictions of Sustainable Development. Journal of the American Planning Association, 62, 296-312. https://doi.org/10.1080/01944369608975696

Carbone, F., Oosterbeek, L., \& Costa, C. (2012). The Educational and Awareness Purposes of the Paideia Approach for Heritage Management. Natural Hazards and Earth System Sciences, 12, 1983-1986. https://doi.org/10.5194/nhess-12-1983-2012

Conrad, E., Christie, M., \& Fazey, I. (2011). Understanding Public Perceptions of Landscape: A Case Study from Gozo, Malta. Applied Geography, 31, 159-170.

CAPE (2004). Design of Outdoor Urban Spaces with Bioclimatic Criteria.

Davies, S. R., Selin, C., Gano, G., \& Pereira, Â. G. (2012). Citizen Engagement and Urban Change: Three Case Studies of Material Deliberation. Cities, 29, 351-357.

de Groot, M., Winnubst, M. H., van Schie, N., \& van Ast, J. A. (2014). Visioning with the Public: Incorporating Public Values in Landscape Planning. European Planning Studies, 22, 1165-1181.

Deeben, J., Groenewoudt, B. J., Hallewas, D. P., \& Willems, W. J. H. (1999). Proposals for a Practical System of Significance Evaluation in Archaeological Heritage Management. European Journal of Archaeology, 2, 177-199. https://doi.org/10.1179/eja.1999.2.2.177

Déjeant-Pons, M. (2006). The European Landscape Convention. Landscape Research, 31, 363-384. https://doi.org/10.1080/01426390601004343

Dreiseitl, H. (2013). In Conversation with Herbert Dreiseitl. Journal of Landscape Architecture, 8, 74-75. https://doi.org/10.1080/18626033.2013.864132 
Dulmin, R., \& Mininno, V. (2003). Supplier Selection Using a Multi-Criteria Decision Aid Method. Journal of Purchasing and Supply Management, 9, 177-187.

E.C. (2006). Landscape and Sustainable Development: Challenges of the European Landscape Convention. Strasbourg Cedex.

Echenique, M. H., Hargreaves, A. J., Mitchell, G., \& Namdeo, A. (2012). Growing Cities Sustainably. Journal of the American Planning Association, 78, 121-137. https://doi.org/10.1080/01944363.2012.666731

ELC (2011). European Landscape Convention. Florence Convention 2007. http://conventions.coe.int/Treaty/en/Treaties/Html/176.htm

Eurostat (2013). Eurostat Regional Yearbook 2013 Statistical Books. European Commission.

FAO (2011). Soil Permeability. ftp://ftp.fao.org/fi/CDrom/FAO_Training/FAO_Training/General/x6706e/x6706e09.ht m\#top

Friedmann, J. (1998). Planning Theory Revisited. European Planning Studies, 6, 245-253. https://doi.org/10.1080/09654319808720459

Fylaktou-Cattaneo, A. (2004). Urban Conservation and Sustainability A Historic Centre. Paper presented at the Plea 2004, The 21st Conference on Passive and Low Energy Architecture, Eindhoven, The Netherlands, 19-22 September 2004.

G.S.P.W. (2011). General Secretariat of Public Works. www.ggde.gr/index.php?option=com_docman\&task=cat_view\&gid=96\&dir=DESC\&or $\underline{\text { der }=\text { name\&limit }=5 \& \text { limitstart }=5}$

Galani, D. (2004). Programme of Unification of Archaeological Sites of Athens. The Restoration of the Historic City. Center Unification of Archaeological Sites of Athens S.A.

Gehl, J. (2002). International Experience. Paper presented at the Documents 10th Greek Architectural Conference, Sadas, Greek Association of Architects: Technical Chamber of Greece Athens.

Gouridis, A. (Ed.) (2007). Didimoticho Travelogue Prehistory Antiquity Byzantium Othoman Empire Modern Times. Alexandroupolis: Prefecture Evros.

Gouridis, I. A. (2006). Didimoticho, an Unknown Capital (pp. 59-67, 108, 134, 146, 147, 159). Komotini: Prefectural Administration of Rodopi-Evros Guide. (2011). Guide of Region of Eastern Macedonia-Thrace, The Climate.

http://www.xanthi.ilsp.gr/cultureportalweb/article.php?article_id=298\&topic_id=19\&le vel=2\&belongs=15\&area_id=18\&lang=gr

Hammond, G., \& Craig, J. (2006). Inventory of Carbon \& Energy (ICE) Embodied Energy of Various Materials and Technology. Data and Summary-1 Bath University.

Hassan, G. F., El Hefnawi, A., \& El Refaie, M. (2011). Efficiency of Participation in Planning. Alexandria Engineering Journal, 50, 203-212.

Hidle, K., \& Leknes, E. (2012). Policy Strategies for New Regionalism: Different Spatial Logics for Cultural and Business Policies in Norwegian City Regions. European Planning Studies, 22, 126-142. https://doi.org/10.1080/09654313.2012.741565

Horne, R. (2008). Embodied Energy in Buildings: A Review. In R. University (Ed.), Melbourne Forum, 30 June.

ICOMOS (1994). The Nara Document of Authenticity. International Council on Monument and Sites.

Iliakis, M. (2011). The Synthetic Tools of D. Pikionis on Filopappou Hill. Architecture, Building Green Magazine, No. 17, 28-33.

Innes, J. E., \& Booher, D. E. (2004). Reframing Public Participation: Strategies for the 21st 
Century. Planning Theory \& Practice, 5, 419-436.

https://doi.org/10.1080/1464935042000293170

Kalioportes (2008). Cultural Association Tampakias Didimotichou Statute. http://kales-portes.blogspot.gr/2008/12/blog-post.html

Kalioportes (2009). Report of Conference "Rivers within the Cities, Blessing or Curse", Redevelopment of the Riverside Erythropotamos and Demonstration of the City's History, Main Demand of Citizens.

http://kalioportes.blogspot.gr/2009_05_01_archive.html

Kapsali, M., \& Potiriadi, I. (2010). Routes in the Landscape with Reference to Dimitris Pikionis Work. Postgraduate Thesis, Athens: EMP.

Karpodini-Dimitriadis, E. (2009). The Spirit of Agricultural Landscapes, Civilization, Memory and Messages. Cult-Rural, Culture 2000, Framework Programme in Support of Culture, Athens.

Kastropolites (2014). Kastropolites Knowledge \& Action.

https://kastropolites.com/kastro_tube/

https://www.youtube.com/watch?v=J_pzzYA9hf8

Kathimerini (1994). Seven Days Sunday 16 October 1994, Special Issue for Pikionis.

Koroneos, E., Poulakos, G., \& Sargentis, G. F. (2004). Green Construction-MaterialsEvaluation. Athens: National Technical University of Athens, Laboratory of Materials of Construction, December 2004.

Kotionis, Z. (2004). The Madness of the Place (pp. 97-117). Athens: Ekkremes Publications.

Koumandakis, I. (2011). Actual Permeability-Hydraulic Conductivity. Athens: EMP, Department of Mining and Metallurgical Department Engineering, Section of Geological Sciences.

Koutsoumanis, M. (2005). The Archaeological Treasure of Plotinopolis. Voreas, No. 5, $31-40$.

Kozyraki, M., \& Tsalikidis, I. A. (2005). Trends in Managing Cultural-Archaeological Landscapes in the Mediterranean: The Example of Central Crete. Paper presented at the Conference Landscape Architecture Education, Research, Applied Project, Thessaloniki.

KU (2011). What Is Sustainability? KU Center for Sustainability. http://www.sustainability.ku.edu/sustainability.shtml

Lahdelma, R., Salminen, P., \& Hokkanen, J. (2000). Using Multicriteria Methods in Environmental Planning and Management. Environmental Management, 26, 595-605. https://doi.org/10.1007/s002670010118

Liberatore, A. (1995). The Social Construction of Environmental Problems. In T. O. University (Ed.), T860: Environmental Decision Making: A Systems Approach, Block 2, Reading 2 (p. 181). Milton Keynes.

Loukaki, A. (2008). Living Ruins, Value Conflicts. Heritage, Culture and Identity (pp. 267-281). Hampshire, England: ASHGATE.

Loures, L., Vargues, P., \& Horta, D. (2008). Landscape Aesthetic and Visual Analysis Facing the Challenge of Development of Sustainable Landscapes-A Case Study of the Post-Industrial Area to the Left Margin of the Arade River. International Journal of Design and Nature and Ecodynamics, 3, 65-74. https://doi.org/10.2495/D\&NE-V3-N1-65-74

Mahdavinejad, M., \& Abedi, M. (2011). Community-Oriented Landscape Design for Sustainability in Architecture and Planning. Procedia Engineering, 21, 337-344. 
Maier, K. (2001). Citizen Participation in Planning: Climbing a Ladder? European Planning Studies, 9, 707-719. https://doi.org/10.1080/09654310120073775

Marcucci, D. J. (2000). Landscape History as a Planning Tool. Landscape and Urban Planning, 49, 67-81.

Martín, J. A. R., Molina, M. D. M. H., \& Fernández, J. A. S. (2012). An Index of Social and Economic Development in the Community's Objective-1 Regions of Countries in Southern Europe. European Planning Studies, 20, 1059-1074. https://doi.org/10.1080/09654313.2012.673571

Matsuoka, R. H., \& Kaplan, R. (2008). People Needs in the Urban Landscape: Analysis of Landscape and Urban Planning Contributions. Landscape and Urban Planning, 84, 7-19.

Matzarakis, A. (2006). The Climate of Evros. Freiburg.

MD (2004). Development of Ministry, General Secretariat for Research and Technology. Integrated Methodological Framework for Decision Support of Decision Making of Evaluation of the Impact of the Introduction of Best Available Techniques in Industry (DAF-BAT), Project Code: FP 19, 1st Work Package 2: Assessment of Current Situation on the Characteristics of Units Athens: National Observatory of Athens.

Mehta, V. (2014). Evaluating Public Space. Journal of Urban Design, 19, 53-88. https://doi.org/10.1080/13574809.2013.854698

Meyer, E. K. (2008). Sustaining Beauty. The Performance of Appearance. Journal of Landscape Architecture, 3, 6-23. https://doi.org/10.1080/18626033.2008.9723392

Ministry-of-Culture-and-Sports. (2017). The Unification of the Archaeological Sites of Athens Retrieved 21/6, 2017, from http://www.yppo.gr/4/e40.jsp?obj_id=90

Mydland, L., \& Grahn, W. (2011). Identifying Heritage Values in Local Communities. International Journal of Heritage Studies, 18, 564-587. https://doi.org/10.1080/13527258.2011.619554

Næss, P. (2001). Urban Planning and Sustainable Development. European Planning Studies, 9, 503-524. https://doi.org/10.1080/09654310120049871

Nama-Marnrt-Salfo (2002). Paving of Outdoor Spaces and Surface Works of Rain Water Drainage. Auction Documents.

Ode, Å., Tveit, M. S., \& Fry, G. (2008). Capturing Landscape Visual Character Using Indicators: Touching Base with Landscape Aesthetic Theory. Landscape Research, 33, 89117. https://doi.org/10.1080/01426390701773854

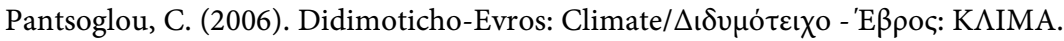
http://www.xanthi.ilsp.gr/cultureportalweb/article.php?article_id=298\&topic_id=19\&le vel=2\&belongs $=15 \&$ area_id $=18 \&$ lang $=$ gr

Papadopoulos, S. (Ed.) (1990). Didimoticho, History Monuments Culture. Didimoticho: Municipality of Didimoticho.

Papageorgiou-Venetas, A. (2005). The "Athenian Walk" and the Historical Landscape of Athens. Paper presented at the Conference Landscape Architecture Education, Research, Applied Project, Thessaloniki.

Patsuridis, P. (2014). Ev $\Delta \iota \delta v \mu o \tau \varepsilon i ́ \chi \omega$. https://www.didymoteicho.gr/images/stories/efimerida/january14.pdf

Pellegrino, P. (2006). The Meaning of Space-The Time and Place (Vol. I, p. 97). Athens: Typothito Giorgos Dardanos.

Poulios, I. (2014). Discussing Strategy in Heritage Conservation: Living Heritage Approach as an Example of Strategic Innovation. Journal of Cultural Heritage Management and Sustainable Development, 4, 16-34. 
https://doi.org/10.1108/JCHMSD-10-2012-0048

Prieur, M. (2006). Landscape and Sustainable Development: Challenges of the European Landscape Convention. Council of Europe Publishing.

Rydin, Y., \& Pennington, M. (2000). Public Participation and Local Environmental Planning: The Collective Action Problem and the Potential of Social Capital. Local Environment, 5, 153-169. https://doi.org/10.1080/13549830050009328

Sandercock, L. (2003). Out of the Closet: The Importance of Stories and Storytelling in Planning Practice. Planning Theory \& Practice, 4, 11-28. https://doi.org/10.1080/1464935032000057209

Sanoff, H. (2008). Multiple Views of Participatory Design. ArchNet-IJAR: International Journal of Architectural Research, 2, 57-69.

Schilling, J., \& Logan, J. (2008). Greening the Rust Belt: A Green Infrastructure Model for Right Sizing America's Shrinking Cities. Journal of the American Planning Association, 74, 451-466. https://doi.org/10.1080/01944360802354956

Schulz, C. N. (2009). Genius Loci The spirit of place For a Phenomenology of Architecture (pp. 5, 49-53, 78-86, 198). Athens: University Publications E.M.P.

Shah, H. P. (2011). Evaluation Criteria for Green Materials. http://www.nbmcw.com/articles/green-construction/17838-evaluation-criteria-for-gree n-materials.html

Sinapidis, S. (2006). Meeting for the Traffic Problem of Didimoticho. http://sinapidistef.blogspot.gr/2006/12/

Sinapidis, S. (2007a). Live the Myth of Didimoticho. Friday, 4 May 2007. http://sinapidistef.blogspot.gr/2007/05/

Sinapidis, S. (2007b). Unification of Historic Sites of Didimoticho. Retrieved from Didimotichou Anavasis. http://sinapidistef.blogspot.gr/2007/01/blog-post_15.html

Sinapidis, S. (2011). 19 April 2011 Meeting-Report City Council of Didimoticho. http://sinapidistef.blogspot.gr/2011/04/

Sovinski, W. R. (2009). Materials and Their Applications in Landscape Design (pp. 1, 2, 3, $111,120)$. Hoboken, NJ: John Wiley \& Sons, Inc.

Stavridis, S. (2006). Memory and Space Experience (p. 24). Athens: Alexandria Publications.

Stephenson, J. (2008). The Cultural Values Model: An Integrated Approach to Values in Landscapes. Landscape and Urban Planning, 84, 127-139.

Stephenson, J. (2010). People and Place. Planning Theory \& Practice, 11, 9-21. https://doi.org/10.1080/14649350903549878

SwC (2011). Stay with Clay, Tiles and Bricks of Europe.

Swensen, G., Jerpåsen, G. B., Sæter, O., \& Tveit, M. S. (2012). Capturing the Intangible and Tangible Aspects of Heritage: Personal versus Official Perspectives in Cultural Heritage Management. Landscape Research, 38, 203-221.

https://doi.org/10.1080/01426397.2011.642346

Tauxe, C. S. (1995). Marginalizing Public Participation in Local Planning: An Ethnographic Account. Journal of the American Planning Association, 61, 471-481. https://doi.org/10.1080/01944369508975658

TET (2011). Climate and Environment, Thracian Electronic Treasure. www.xanthi.ilsp.gr/thraki/per/per4.asp?eidos

Thomas, A., Chataway, J., \& Wuyts, M. (Eds.) (1998). Finding out Fast: Investigative Skills for Policy and Development. London: The Open University SAGE Publications Ltd. 
Tveit, M., Ode, Å., \& Fry, G. (2006). Key Concepts in a Framework for Analysing Visual Landscape Character. Landscape Research, 31, 229-255.

https://doi.org/10.1080/01426390600783269

UNECE (1998). Convention on Access to Information, Public Participation in DecisionMaking and Access to Justice in Environmental Matters (Aarhus Convention). Aarhus, Denmark: United Nations Economic Commission for Europe.

Van Damme, S., Leinfelder, H., \& Uyttenhove, P. (2012). Landscape as a Medium for Integration in Design Practice: The Case of Flanders, Belgium. European Planning Studies, 21, 1128-1152. https://doi.org/10.1080/09654313.2012.722938

Van Eetvelde, V., \& Antrop, M. (2004). Analyzing Structural and Functional Changes of Traditional landscapes-Two Examples from Southern France. Landscape and Urban Planning, 67, 79-95.

Vavelidis, M., Hotzidis, A., \& Melfos, V. (2007). The Quarries and Monuments of North Evros: Factors of Economic Development from Ancient to Contemporary Times (pp. 38-53). Petrota Evrou: Seminar August 2007, Development Opportunities in Northern Evros: Culture, Mineral Resources and the Environment.

Von Haaren, C. (2002). Landscape Planning Facing the Challenge of the Development of Cultural Landscapes. Landscape and Urban Planning, 60, 73-80.

Voudiklaris, G. T., \& Anagnostopoulos, P. (2009). Paving of Outdoor Spaces with Concrete Cobblestones and Cobblestones of New Technology.

Yung, E. H. K., \& Chan, E. H. W. (2011). Problem Issues of Public Participation in BuiltHeritage Conservation: Two Controversial Cases in Hong Kong. Habitat International, 35, 457-466.

ADA: ALAOR1Y-PE (2011). Decision Approving the Environmental Terms for the Operation of the Brick Factory of the Company "CERAMICS EVROS S.A." Which Is Located near the Village of Lepti Orestiada in North Evros. Komotini: Decentralized Administration of Macedonia-Thrace, General Management Department of Planning \& Environmental Policy, Environmental \& Spatial Planning of East Macedonia-Thrace, Department of Environmental Planning.

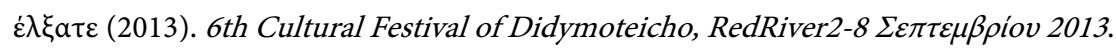
http://www.elxate.gr/302/ 


\section{Appendix A. Analysis of Design Proposals}

"Multiculturalism and diversity" would be a two-word description of the historical landscapes of the town of Didimoticho. The main design elements found in the monuments are rectangular blocks, red bricks embedded in the masonry; round and square formations, curved arches, geometrical and complicated motives, massive grey stones and colourful mosaics (see Figure S1 and Figure S3). The riparian landscape is characterized by biodiversity and the name of the River Erythropotamos literally means the red river [" $\varepsilon \rho v \theta \rho o ́ c$ " "erythros"]. Moreover, its old name "GisilDere" or "Crazy River" comes from the era of the Ottoman Empire, and denotes its torrential character, variability of landscape due to winter floods and considerable reduction in flow over summer. Additionally, low winter temperatures, snowfalls and frequent frosts as well as high summer temperatures and low rainfall rates called for the selection of paving materials that are resistant to extreme changes in climatic conditions, permeable, with high albedo and low slipperiness. Moreover, the lack of natural barriers and prevalence of winds blowing from all directions throughout the year created the need for enrichment of the existing yet degraded local flora.

The majority of respondents $(42.7 \%)$ characterized the landscape along the unification route as complex and thus varied, plural, but uniform, in harmonious balance with nature and as having a distinctive identity; the visual escapes along the route to monuments with a distinctive, imposing presence, such as the castle, caves, the Mosque, the Pentazono and the baths of Ourouts Pasha but also to the flora and fauna of the riparian zone and the quiet but sometimes impetuous presence of water element account for this distinctive identity. According to respondents, the style of paving along this route through the complex landscape should be simple, uniform and symmetric, with straight and curved configurations, with few colours and materials of rough texture, with and sometimes without motives. Younger people mostly described the landscape as "cosmic", with geometric shapes and uniformity and showed greater preference for a complicated and colourful paving, while older respondents stated their preference for asymmetry and rough texture.

In the third and fourth design proposals, the morphological invention of gravel lanes was used while in the sixth; lanes of red granite cobblestones were used. The main elements of the simple, austere design approach were geometric lines, uniformity, symmetry and use of different materials with rough texture. The second proposal had curved formations, while the third, fourth and sixth ones linear, simple motives to meet these two design preferences. Natural coloured materials, which fit best the landscape but also the morphology of the monuments, were used. Respect for the landscape and historic heritage, the encouragement of social activities and contacts and movement, which also involves the sense of continuous flow of running water, constituted the main design guidelines of the proposed design approaches (Figure A1).

\section{Appendix B. Calculations}

The weight scores of "Wants" were calculated as follows, according to five sus- 

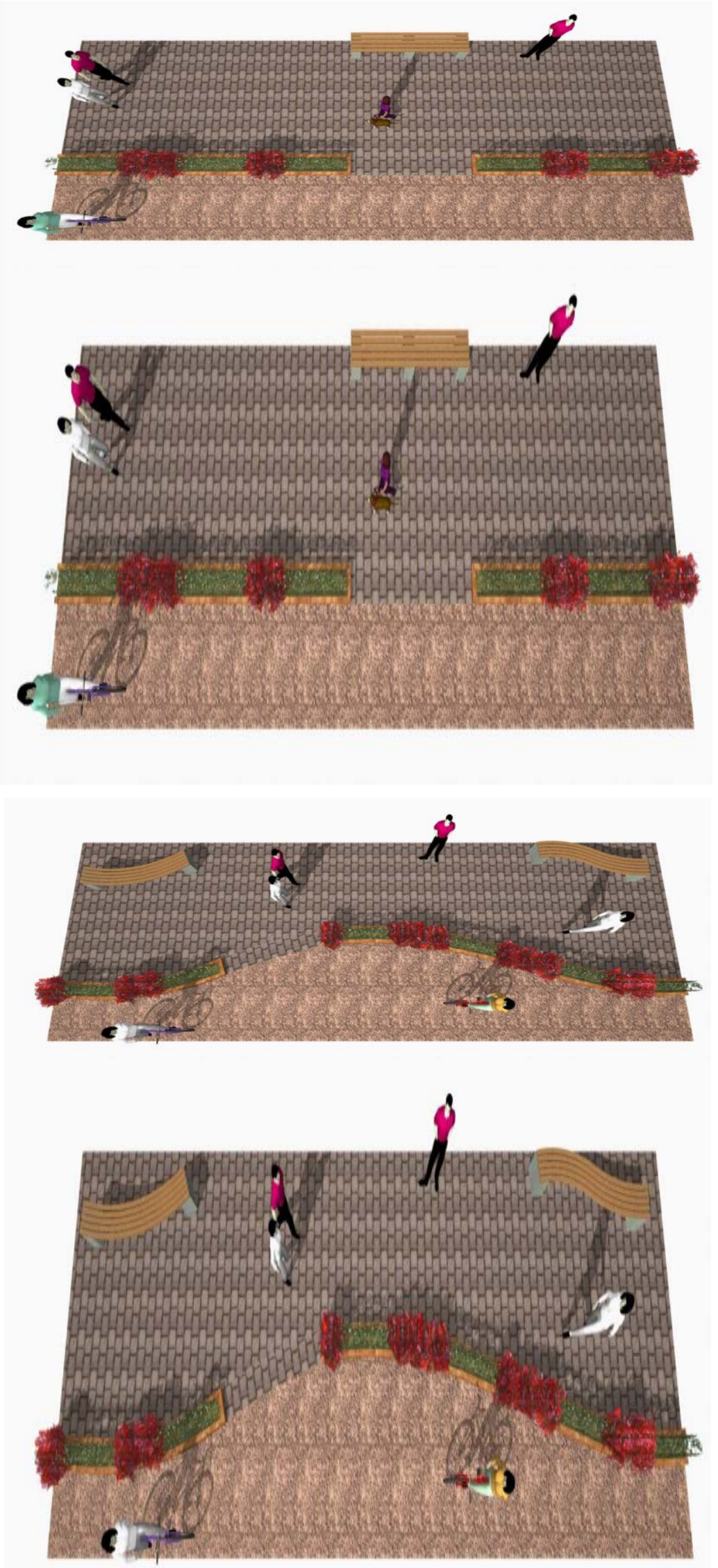

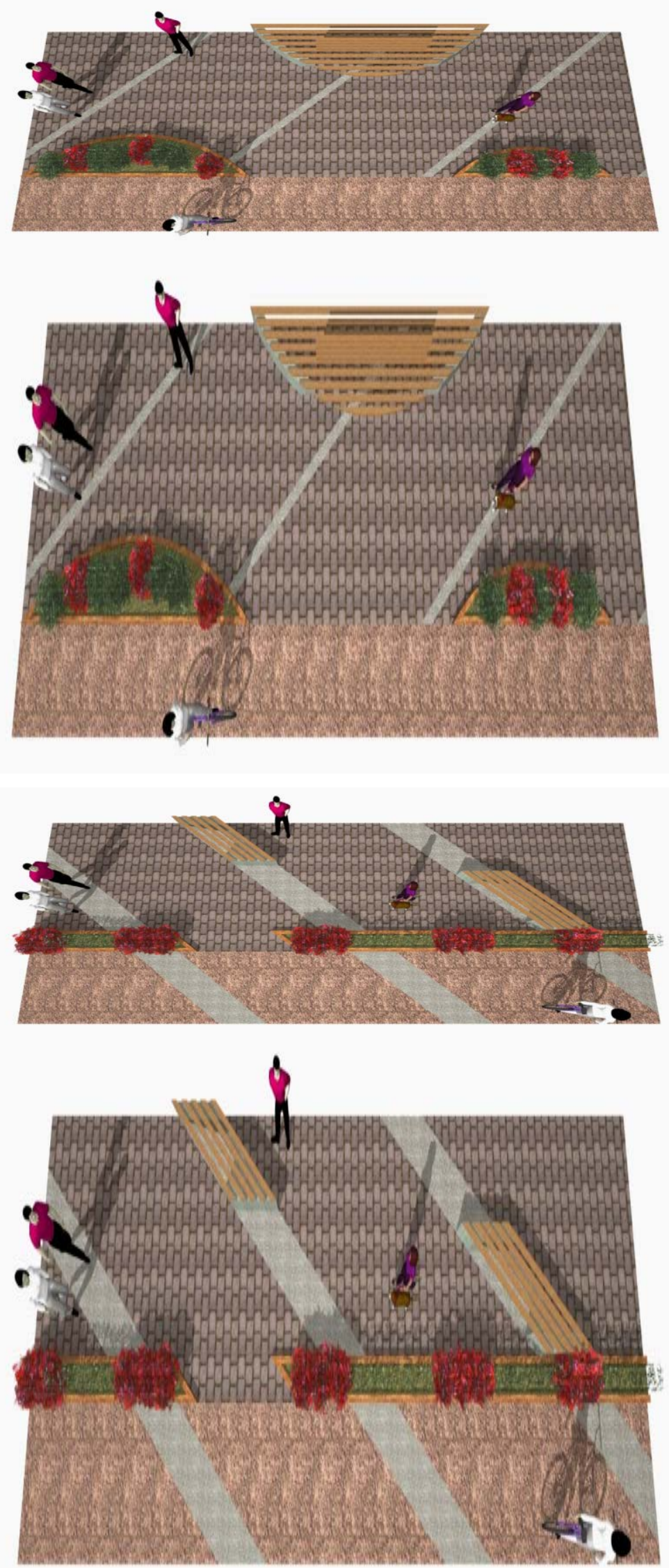

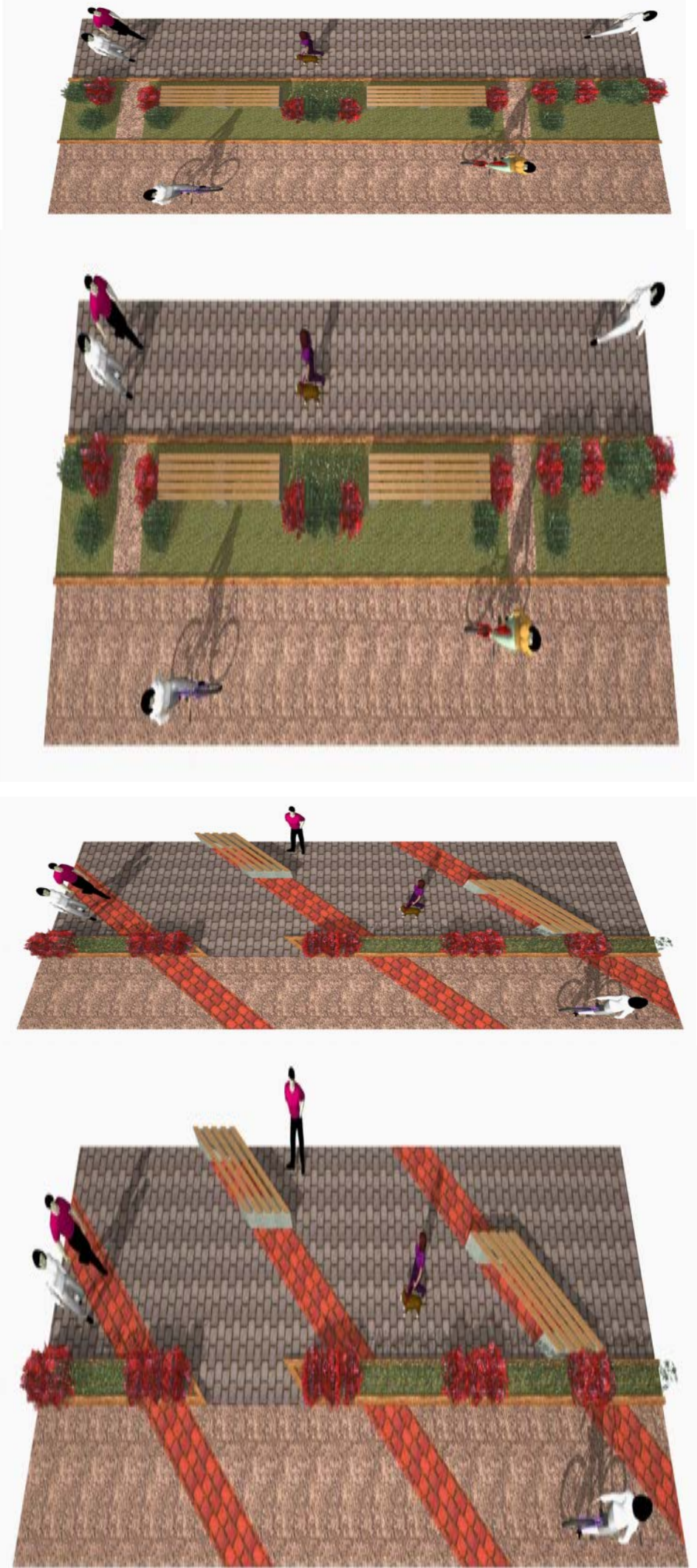

Figure A1. The design proposals: (a) first, (b) second, (c) third, (d) forth, (e) fifth and (f) sixth. 
tainability criteria: construction cost of paving, local availability, albedo, embodied energy and permeability of materials used. Initially, a total score (TS) was estimated with the Equation (B1) and then it was reduced to scale " 0 - 1 " Wants score (WS) with the Equation (B2) for the criteria of local availability, albedo and permeability.

$$
\begin{aligned}
& \mathrm{TS}_{j c}= \operatorname{Acg}_{j} * \mathrm{Ccg}_{c}+\mathrm{As}_{j} * \mathrm{Cs}_{c}+A g_{j} * \mathrm{Cg}_{c}+\mathrm{Ab}_{j} * \mathrm{Cb}_{c} \\
&+\operatorname{Acr}_{j} * \mathrm{Ccr}_{c}+\operatorname{Agr}_{j} * \mathrm{Cgr}_{c} \\
& \mathrm{WS}_{j c}=0.5 *\left[\frac{\mathrm{TS}_{j c}}{\frac{\mathrm{TS}_{j c} \min +\mathrm{TS}_{j c} \max }{2}}\right]
\end{aligned}
$$

where: Acg surface of grey cobblestone, As surface of soil, Ag surface of greenery, Ab surface of brick, Acr surface of red cobblestone and Agr surface of gravel, Ccg criterion points for grey cobblestone, Cs criterion points for soil, Cg criterion points for greenery, $\mathrm{Cb}$ criterion points for brick, $\mathrm{Ccr}$ criterion points for red cobblestone and Cgr criterion points for gravel for the proposal $j$ $(j=1,2, \cdots, 6)$ and criterion $c(c=1,2, \cdots, 5)$.

$$
\mathrm{WS}_{j c}=0.5 *\left[\frac{\frac{\mathrm{TS}_{j c} \min +\mathrm{TS}_{j c} \max }{2}}{\mathrm{TS}_{j c}}\right]
$$

High scores for cost and embodied energy were not desirable, contrary to local availability, albedo and permeability, so the reduction to scale " 0 - 1 " Wants score (WS) was calculated with the Equation (B3).

a) 1st Criterion: Construction cost

The concept of sustainability apart from social responsibility, equal opportunities for everyone to participate in decision-making and the environmental dimension, includes also an economic dimension (KU, 2011), which in this case was expressed by calculating the construction cost of each design proposal (Table B1).

There is a standard cost for all proposals which results from the destruction of asphalt and landfilling for a surface of $108 \mathrm{~m}^{2}, \mathrm{a}=372.60 €$.

b) 2nd Criterion: Local availability of materials

Table B1. Cost of materials and labour (G.S.P.W., 2011).

\begin{tabular}{ccc}
\hline Materials + Labour & Unit & $€$ \\
Destruction of asphalt & $\mathrm{m}^{2}$ & 0.37 \\
Landfilling (thickness $0.5 \mathrm{~m}$ ) & $\mathrm{m}^{3}$ & 6.16 \\
Greenery frieze (short indigenous plants) & $\mathrm{m}^{2}$ & 2.80 \\
Construction of packed soil (thickness of packed soil 1 m) & $\mathrm{m}^{3}$ & 10.50 \\
Paving with granite cobblestones & $\mathrm{m}^{2}$ & 40.00 \\
Paving with bricks & $\mathrm{m}^{2}$ & 15.00
\end{tabular}


Preference for local materials contributes to reduction of energy consumption for the transportation of materials and hence greenhouse gas emissions (Table B2).

The municipality of Didimotihon leases 14 acres quarries for the extraction of inert materials and a brick manufacturing plant operates at a distance of $22 \mathrm{~km}$, in the village of Lepti, Orestiada. The extraction and exploitation of stone is an activity that has long been abandoned in the region and therefore the closest place for cobblestones supplies is Kavala (Sinapidis, 2011; Vavelidis, Hotzidis, \& Melfos, 2007). Native species of greenery was proposed to be planted in the greenery friezes (Table B3).

c) 3rd Criterion: Albedo of materials

The use of dark materials in buildings and pavements along, with the lack of adequate vegetation in cities, which acts as a natural factor that contributes to air cooling, result in warming surfaces and air in urban environments (Urban Heat Island). On hot summer days, the temperature of air in the urban environments can be from $3^{\circ}$ up to $10^{\circ} \mathrm{C}$ higher than in suburban areas (Voudiklaris \& Anagnostopoulos, 2009).

White or coloured materials can be used on surfaces of urban buildings in order to reduce their temperature. Compared with conventional materials of the same colour, cold materials are characterized by high reflectivity of solar radiation, and high emissivity of infrared radiation because they emit the amounts of heat absorbed faster. Their use can secure lower surface temperatures compared to other paving materials (Table B4).

d) $4^{\text {th }}$ Criterion: Embodied energy

The embodied energy of materials includes the energy required for extraction of raw materials from nature, their transport to manufacturing unit and the

Table B2. Evaluation of materials according to local availability (Shah, 2011).

\begin{tabular}{cc}
\hline Distance from the place of manufacturing & Points \\
$0-20 \mathrm{~km}$ & 1.0 \\
$21-50 \mathrm{~km}$ & 0.8 \\
$51-100 \mathrm{~km}$ & 0.6 \\
$101-200 \mathrm{~km}$ & 0.2 \\
$>200 \mathrm{~km}$ & 0.0
\end{tabular}

Table B3. Evaluation of design proposals materials according to local availability.

\begin{tabular}{ccc}
\hline Materials & Distance from the place of manufacturing & Points \\
\hline Cobblestones & $>200 \mathrm{~km}$ & 0.0 \\
Soil & $0-20 \mathrm{~km}$ & 1.0 \\
Greenery & $0-20 \mathrm{~km}$ & 0.8 \\
Bricks & $21-50 \mathrm{~km}$ & 1.0 \\
Gravel & $0-20 \mathrm{~km}$ & 1.0 \\
\hline
\end{tabular}


Table B4. Classification of paving materials according to albedo (CAPE, 2004).

\begin{tabular}{cc}
\hline Paving material & Albedo $\left(\right.$ per $\left.\mathrm{m}^{2}\right)$ \\
\hline Black asphalt & \\
Dark concrete & $0.1-0.3$ \\
$\quad$ Greenery & \\
$\quad$ Slate & \\
Light coloured concrete & \\
Oxidized copper & \\
Red bricks & \\
$\quad$ Stone & $0.4-0.6$ \\
Limestone & \\
Marble & \\
White coat & $0.7-0.9$ \\
& \\
\hline
\end{tabular}

energy used in the plant for the provision of finished materials (Shah, 2011). Embodied energy is an indicator of the overall environmental impact of the production of a paving material (Table B5).

e) 5th Criterion: Permeability of materials

Cobblestones and bricks are placed on a layer of sand leaving joints, which in the case of straight line formations are place $5 \mathrm{~mm}-10 \mathrm{~mm}$ apart, allowing the movement of rain water to underground aquifers (Nama-Marnrt-Salfo, 2002; Sovinski, 2009). However, these materials compared to gravel, plant material and soil are considered impermeable (Table B6).

1) Other Criteria of Sustainability

The recyclability of paving materials, the use of materials in percentage, coming from recycling, long life cycle and low maintenance requirements are also considered as sustainability criteria (Shah, 2011). As regards these criteria, materials, such as soil, cobblestones, bricks and gravel are completely recyclable, have no particular maintenance requirements and a long life cycle. Moreover, planting of indigenous species without high water requirements and high maintenance cost is considered appropriate (Beckman et al., 2001).

Pollution such as emissions of volatile compounds, dioxins or heavy metals released in the environment, caused by mining, production process, use or disposal at the end of the useful life of a material, could serve as yet another evaluation criterion (Shah, 2011). Emissions from the conversion of raw material into brick, apart from carbon dioxide, carbon monoxide, nitrogen oxides and particles, include hydrochloric, hydrofluoric and sulfuric acids (SwC, 2011; ADA: ALAOR1Y-PE, 2011). The production process of natural stone blocks does not release such pollutants in the environment (MD, 2004). Given the small differences between the areas of paving brick of the proposals, this criterion was not considered as important for their evaluation.

2) Final Results

The final weight factors "Wants" for each proposal which resulted by adding the points of all criteria can be seen in Table B7 and Table B8. 
Table B5. Embodied energy (Hammond \& Craig, 2006; Horne, 2008; Koroneos, Poulakos, \& Sargentis, 2004).

\begin{tabular}{ccc}
\hline Materials & \multicolumn{1}{c}{ Embodied energy } \\
\hline Granite (cobblestones $10 \mathrm{~cm}$ in height) & $65 \mathrm{MJ} / \mathrm{kg}$ & $94.25 \mathrm{MJ} / \mathrm{m}^{2}$ \\
Brick (weight $1.45 \mathrm{~kg} / \mathrm{dm}^{3}$ ) & $2.5 \mathrm{MJ} / \mathrm{m}^{2}$ & $2.50 \mathrm{MJ} / \mathrm{m}^{2}$ \\
Gravel (thickness of gravel paving $0.20 \mathrm{~m}$ ) & $780 \mathrm{MJ} / \mathrm{m}^{3}$ & $156.00 \mathrm{MJ} / \mathrm{m}^{2}$ \\
\hline
\end{tabular}

Table B6. Indicative value of permeability coefficient of paving materials (FAO, 2011; Koumandakis, 2011).

\begin{tabular}{cccc}
\hline Materials & Permeability cm/sec & Rankings & Coefficient definition \\
\hline Granite & $10^{-8}$ & Impervious & 0.0 \\
Packed soil & $1.388 \times 10^{-5}$ & Semi-pervious & 0.5 \\
Gravel & 0.0014 & Pervious & 1.0 \\
\hline
\end{tabular}

Table B7. Total points of the five criteria and definition of Wants for each criterion.

\begin{tabular}{cccccccccccc}
\hline $\begin{array}{c}\text { Design } \\
\text { Proposals } \\
\text { (j) }\end{array}$ & $\begin{array}{c}\text { Total } \\
\text { cost }\end{array}$ & \multicolumn{3}{c}{$\begin{array}{c}\text { Local } \\
\text { availability }\end{array}$} & Albedo & \multicolumn{3}{c}{$\begin{array}{c}\text { Embodied } \\
\text { energy }\end{array}$} & \multicolumn{3}{c}{ Permeability } \\
\hline st & 3450 & 0.426 & 40.54 & 0.373 & 39.04 & 0.536 & 6313 & 0.460 & 21.92 & 0.310 \\
2nd & 3432 & 0.429 & 42.00 & 0.386 & 38.64 & 0.530 & 6214 & 0.467 & 22.12 & 0.312 \\
3rd & 3491 & 0.421 & 38.76 & 0.356 & 41.73 & 0.572 & 7146 & 0.407 & 23.41 & 0.331 \\
4th & 2897 & 0.508 & 56.40 & 0.519 & 42.24 & 0.579 & 7769 & 0.374 & 39.32 & 0.555 \\
5th & 2345 & 0.627 & 71.28 & 0.655 & 30.67 & 0.421 & 3851 & 0.754 & 50.40 & 0.712 \\
6th & 3540 & 0.416 & 37.48 & 0.345 & 38.45 & 0.527 & 6601 & 0.440 & 20.40 & 0.288 \\
\hline
\end{tabular}

Table B8. Calculation of final weight factors "Wants" for each proposal.

\begin{tabular}{ccccccc}
\hline \multirow{2}{*}{$\begin{array}{c}\text { Design } \\
\text { Proposals (j) }\end{array}$} & 1st & 2nd & 3rd & 4 th & 5 th & $\begin{array}{c}\text { Final } \\
\text { scores } \\
\text { "Wants" }\end{array}$ \\
\cline { 2 - 5 } 1st & 0.426 & 0.373 & 0.536 & 0.460 & 0.310 & 2.105 \\
2nd & 0.429 & 0.386 & 0.530 & 0.467 & 0.312 & 2.124 \\
3rd & 0.421 & 0.356 & 0.572 & 0.407 & 0.331 & 2.087 \\
4th & 0.508 & 0.519 & 0.579 & 0.374 & 0.555 & 2.535 \\
5th & 0.627 & 0.655 & 0.421 & 0.754 & 0.712 & 3.169 \\
6th & 0.416 & 0.345 & 0.527 & 0.440 & 0.288 & 2.016 \\
\hline
\end{tabular}

\section{Appendix C. Socio-Economic Parameters and Descriptive Statistics}

1) Socio-Economic Parameters and Their Impact on the Design Approach

Female respondents were more likely to choose the frieze of greenery to separate different road services $\left(\chi^{2}=4.770, p=0.029\right)$. Older people were more likely to 
prefer a low traffic road $(r=0.195, p=0.030)$ and frieze of greenery $(r=0.204$, $p=0.023)$. On the other hand, young people were more likely to describe the landscape as cosmic $(r=-0.199, p=0.027)$. Respondents with high academic credentials were more probable to prefer the frieze of greenery $(r=0.191, p=$ $0.034)$. The more the children a family has, the more probable the characterization of landscape as cosmic has been $(r=0.223, p=0.014)$, while the fewer the children a family has, the more probable the characterization of landscape as romantic has been $(r=-0.205, p=0.024)$.

In relation to aesthetics, younger respondents were more probable to select complicated $(r=-0.181, p=0.045)$ and colourful paving $(r=-0.247, p=0.006)$, while older ones asymmetric paving $(r=0.223, p=0.013)$ with rough texture $(r=0.247, p=0.006)$. Low educated respondents and those with more children in the family were more probable to select paving with many colours $(r=-0.308$, $p=0.001 ; r=0.247, p=0.007$ respectively). On the other hand, high educated respondents were more probable to show a strong preference for paving without motives $(r=0.192, p=0.032)$.

2) Descriptive Statistics

The majority (83.1\%) of the respondents stated that they had poor knowledge of the history of the town's monuments and archaeological sites, while $76.6 \%$ stated that they knew a legend or folktale related to the history of the town. In general, respondents knew the meaning of the names of three out of the seven places included in our survey, "Tower of princess" (58.9\%), "Castle" (Kales) (58.9\%) and "The town of Plotini" (Plotinopolis) (57.3\%), while they stated ignorance of the meaning of the "Castle gates" (Kalioportes) (55.3\%), "Five belts" (Pentazono) (72.6\%), "Saint Stone" (Agia Petra) (57.3\%) and "Andiron" (Pyrostia) (61.3\%). $60.5 \%$ of the respondents visit the Castle archaeological site at least once a year.

Additionally, residents were requested to evaluate the importance of archaeological sites degradation parameters. The respective results are presented in $\mathrm{Ta}-$ ble C1. Five ordered response levels were used from "Least important" to "Most important", while an importance rank was created by ranking the sum of "Very important" and "Most important" categories as seen in the last column of Table C1. Figures imply that the most important degradation parameter of archaeological sites was the "rubbish everywhere", followed by the "generally degraded image of landscape" and the "difficult access to sites" parameters (Table C1).

Concerning the landscape, the most important reason that would discourage residents from taking a walk along the river Erythropotamos was the "rubbish everywhere" parameter followed by the "generally degraded image of landscape" and the "presence of annoying insects" especially during summer (Table C2).

Only $11.3 \%$ of the respondents had any substantial knowledge and information about the biodiversity of the region, while nobody stated "Absolutely informed". With regard to the values of traditional landscape, the "intrinsic value of all creatures and biodiversity" was high in the importance rank, followed by the "conservation of natural resources" and "conservation of landscapes for future generations" (Table C3). 
Table C1. Evaluation of importance of degradation parameters of archaeological sites (in percent).

\begin{tabular}{|c|c|c|c|c|c|c|}
\hline Degradation parameters & $\begin{array}{c}\text { Least } \\
\text { important }\end{array}$ & $\begin{array}{l}\text { Less } \\
\text { important }\end{array}$ & $\begin{array}{l}\text { Neither } \\
\text { important nor } \\
\text { unimportant }\end{array}$ & $\begin{array}{c}\text { Very } \\
\text { important }\end{array}$ & $\begin{array}{c}\text { Most } \\
\text { important }\end{array}$ & $\begin{array}{l}\text { Importance } \\
\text { rank }\end{array}$ \\
\hline Lack of information signs & 14.5 & 12.1 & 18.5 & 33.1 & 21.8 & 4 \\
\hline Difficult access to sites & 10.5 & 6.5 & 25.0 & 28.2 & 29.8 & 3 \\
\hline Many weeds & 18.5 & 14.5 & 14.5 & 22.6 & 29.8 & 6 \\
\hline Presence of rubbish everywhere & 10.5 & 5.6 & 13.7 & 25.0 & 45.2 & 1 \\
\hline $\begin{array}{c}\text { The tour around the sites is } \\
\text { not attractive }\end{array}$ & 18.5 & 14.5 & 25.0 & 19.4 & 22.6 & 14 \\
\hline $\begin{array}{l}\text { Bad condition of sites because of the } \\
\text { limited maintenance and } \\
\text { restoration of the monuments }\end{array}$ & 10.5 & 12.1 & 24.2 & 26.6 & 26.6 & 5 \\
\hline $\begin{array}{c}\text { The generally degraded image of } \\
\text { landscape }\end{array}$ & 10.5 & 7.3 & 19.4 & 27.4 & 35.5 & 2 \\
\hline $\begin{array}{l}\text { Lack of excavation and research activity, } \\
\text { keeping them partially inaccessible }\end{array}$ & 12.9 & 9.7 & 28.2 & 25.0 & 24.2 & 9 \\
\hline $\begin{array}{l}\text { Inadequate promotion with visual } \\
\text { material and educational programmes }\end{array}$ & 12.1 & 12.1 & 34.7 & 16.9 & 24.2 & 16 \\
\hline Lack of security & 16.1 & 18.5 & 24.2 & 21.8 & 19.4 & 15 \\
\hline Insufficient lighting & 12.9 & 17.7 & 21.0 & 26.6 & 21.8 & 11 \\
\hline Presence of stray animals & 17.7 & 15.3 & 16.9 & 25.0 & 25.0 & 8 \\
\hline $\begin{array}{l}\text { The sites are unsafe (danger of falling } \\
\text { rocks, dangerous crossing points) }\end{array}$ & 15.3 & 8.1 & 25.0 & 25.8 & 25.8 & 7 \\
\hline $\begin{array}{l}\text { Lack of traced paths that allow better } \\
\text { orientation towards the sites and } \\
\text { observation of monuments }\end{array}$ & 11.3 & 15.3 & 24.2 & 18.5 & 30.6 & 10 \\
\hline $\begin{array}{l}\text { Presence of annoying insects, } \\
\text { especially during summer }\end{array}$ & 19.4 & 12.9 & 17.7 & 23.4 & 26.6 & 8 \\
\hline The tour route is tiring & 31.5 & 20.2 & 29.0 & 10.5 & 8.9 & 17 \\
\hline Odours at the site & 12.1 & 20.2 & 23.4 & 21.0 & 23.4 & 12 \\
\hline $\begin{array}{l}\text { Lack of protection from the winds } \\
\text { and sun (sheltered rest places, } \\
\text { appropriate tree planting) }\end{array}$ & 19.4 & 10.5 & 26.6 & 25.0 & 18.5 & 13 \\
\hline
\end{tabular}

Cronbach's alpha was used to assess the internal consistency and reliability of the 18 items of historical sites degradation, 9 items of natural landscape degradation and 12 items of importance of values related to traditional landscape. The value of alpha was high in all cases, $0.893,0.793$ and 0.891 for the parameters presented in Tables C1-C3 respectively. This means that when respondents tended to assess a parameter as very important, they also considered the other parameters as very important. Consequently, when they considered an item less 
Table C2. Evaluation of importance of degradation parameters of Erythropotamos valley (in percent).

\begin{tabular}{|c|c|c|c|c|c|c|}
\hline Degradation parameters & $\begin{array}{c}\text { Least } \\
\text { important }\end{array}$ & $\begin{array}{c}\text { Less } \\
\text { important }\end{array}$ & $\begin{array}{l}\text { Neither } \\
\text { important nor } \\
\text { unimportant }\end{array}$ & $\begin{array}{c}\text { Very } \\
\text { important }\end{array}$ & $\begin{array}{c}\text { Most } \\
\text { important }\end{array}$ & $\begin{array}{l}\text { Importance } \\
\text { rank }\end{array}$ \\
\hline Presence of rubbish & 8.9 & 1.6 & 8.1 & 24.2 & 57.3 & 1 \\
\hline $\begin{array}{l}\text { Presence of annoying insects, } \\
\text { especially during summer }\end{array}$ & 6.5 & 14.5 & 17.7 & 22.6 & 38.7 & 3 \\
\hline The tour route is tiring & 38.7 & 24.2 & 21.8 & 5.6 & 9.7 & 9 \\
\hline $\begin{array}{l}\text { The generally degraded image } \\
\text { of landscape }\end{array}$ & 6.5 & 6.5 & 15.3 & 33.9 & 37.9 & 2 \\
\hline Odours at the site & 10.5 & 7.3 & 23.4 & 21.8 & 37.1 & 4 \\
\hline $\begin{array}{l}\text { Lack of protection from the winds and } \\
\text { sun (sheltered rest places, appropriate } \\
\text { tree planting) }\end{array}$ & 18.5 & 14.5 & 23.4 & 20.2 & 23.4 & 7 \\
\hline Insufficient lighting & 15.3 & 20.2 & 22.6 & 21.0 & 21.0 & 8 \\
\hline Presence of stray animals & 10.5 & 14.5 & 26.6 & 19.4 & 29.0 & 6 \\
\hline $\begin{array}{l}\text { The route is unsafe because } \\
\text { of passing vehicles }\end{array}$ & 9.7 & 11.3 & 23.4 & 22.6 & 33.1 & 5 \\
\hline
\end{tabular}

Table C3. Importance of values related to traditional landscape (in percent).

\begin{tabular}{|c|c|c|c|c|c|c|}
\hline $\begin{array}{l}\text { Values related to traditional } \\
\text { landscape }\end{array}$ & $\begin{array}{c}\text { Least } \\
\text { important }\end{array}$ & $\begin{array}{c}\text { Less } \\
\text { important }\end{array}$ & $\begin{array}{c}\text { Neither } \\
\text { important nor } \\
\text { unimportant }\end{array}$ & $\begin{array}{c}\text { Very } \\
\text { important }\end{array}$ & $\begin{array}{c}\text { Most } \\
\text { important }\end{array}$ & $\begin{array}{l}\text { Importance } \\
\text { rank }\end{array}$ \\
\hline $\begin{array}{l}\text { Entertainment and leisure } \\
\text { activities in the town }\end{array}$ & 8.1 & 5.6 & 25.8 & 35.5 & 25.0 & 10 \\
\hline $\begin{array}{l}\text { Entertainment and leisure } \\
\text { activities in nature }\end{array}$ & 3.2 & 9.7 & 16.1 & 34.7 & 36.3 & 7 \\
\hline Biodiversity & 2.4 & 9.7 & 16.1 & 33.1 & 38.7 & 6 \\
\hline Historic heritage & 3.2 & 6.5 & 21.0 & 27.4 & 41.9 & 8 \\
\hline $\begin{array}{l}\text { Economic development } \\
\text { (possible tourist attraction) }\end{array}$ & 4.8 & 6.5 & 12.1 & 35.5 & 41.1 & 4 \\
\hline Environmental education & 4.0 & 7.3 & 16.1 & 41.1 & 31.5 & 5 \\
\hline Picturesqueness of landscape & 3.2 & 8.1 & 22.6 & 30.6 & 35.5 & 9 \\
\hline $\begin{array}{l}\text { Spirituality (religiousness, } \\
\text { meditation, contemplation) }\end{array}$ & 12.1 & 16.1 & 28.2 & 29.8 & 13.7 & 11 \\
\hline $\begin{array}{l}\text { Conservation of landscapes } \\
\text { for future generations }\end{array}$ & 5.6 & 3.2 & 12.9 & 29.8 & 48.4 & 3 \\
\hline $\begin{array}{l}\text { Conservation of natural resources } \\
\text { (soil, water) }\end{array}$ & 2.4 & 8.1 & 10.5 & 23.4 & 55.6 & 2 \\
\hline $\begin{array}{l}\text { Health (activities for } \\
\text { fitness and mentality) }\end{array}$ & 3.2 & 8.1 & 12.1 & 21.8 & 54.8 & 4 \\
\hline Intrinsic value of all creatures & 4.0 & 3.2 & 11.3 & 24.2 & 57.3 & 1 \\
\hline
\end{tabular}

important, they also tended to assess the rest of the items as less important. 


\section{Supported Materials}

This file provides supplementary information through photographs. Figure S1 presents monuments of the Byzantine and Ottoman Empire periods; Figure S2 illustrates detail of the final product of the workshop "How we want the riverside" which took place during the RedRiver festival 2009; Figure S3 represents the most important findings of the ongoing excavation in Plotinopolis and Figure $\mathrm{S} 4$ shows the south-eastern side of the castle.

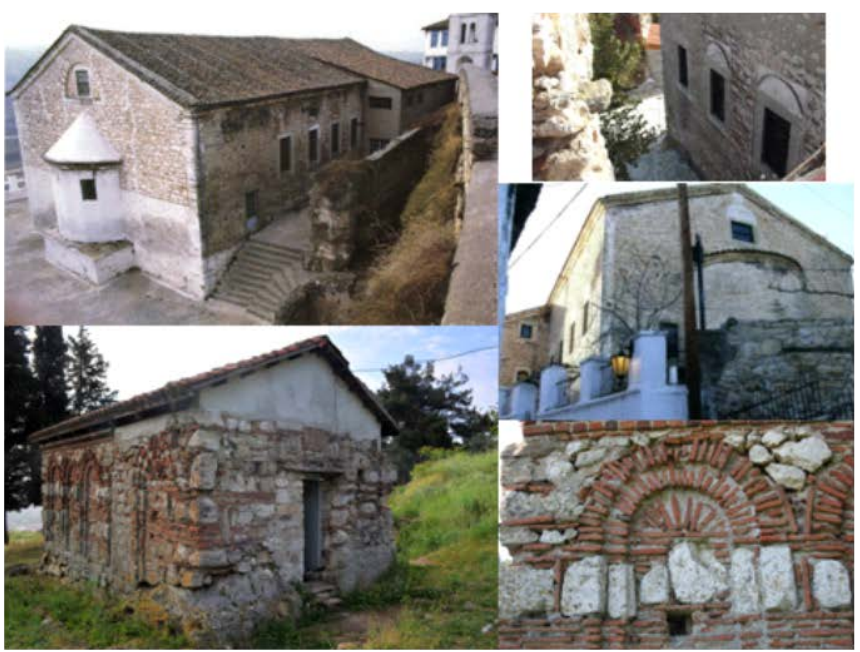

(a)

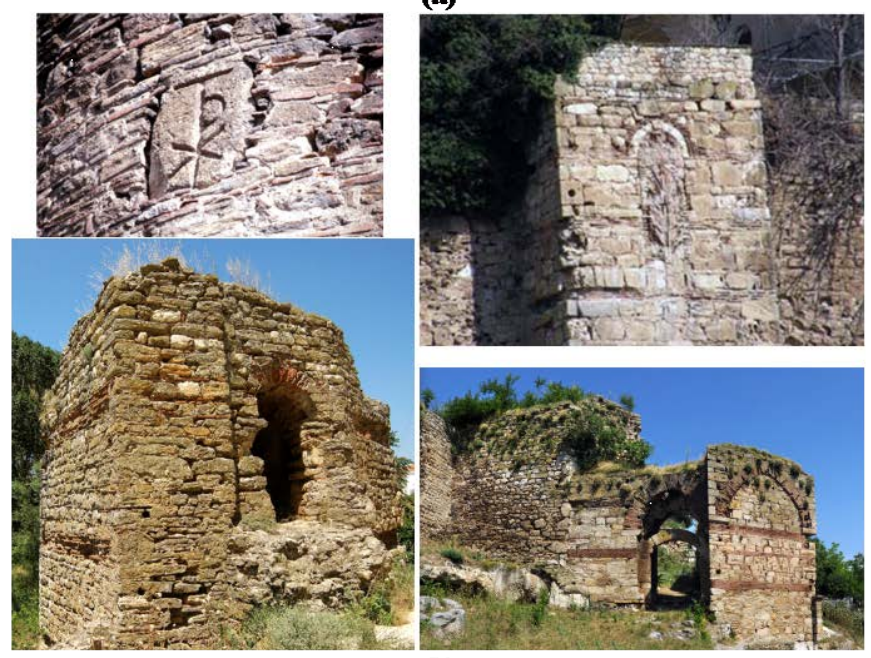

(b)

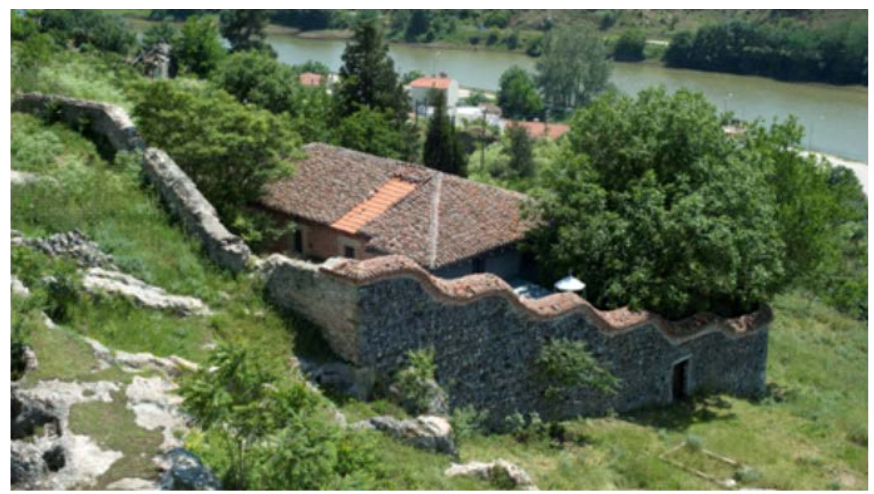

(c) 


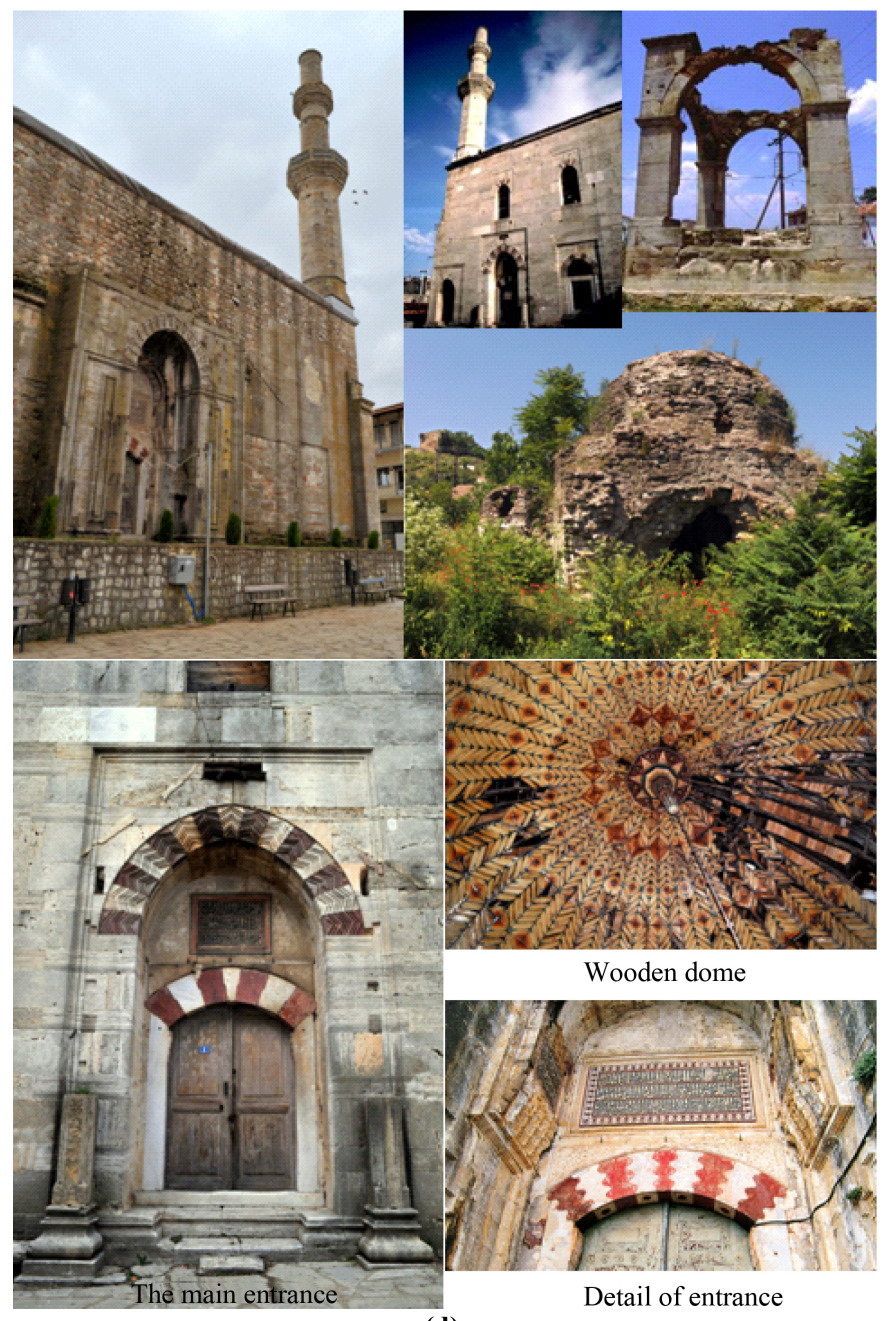

(d)

Figure S1. (a) Byzantine churches in the castle: Agios Athanasios (1834), Sotiros Christou (1848) and Agia Aikaterini (14th century); (b) Towers of the castle walls (6th century): details of the towers, Pentazono and Kalioportes gates; (c) the Armenian church of Surp Kevork in the castle (1815-31); (d) Monuments of the Ottoman Empire: the Vagiazit Mosque (1361-1420), Pyrostia (1892), Ourouts Pasa's baths (1398) and details of the Mosque (Municipality, 2014; T.E.T., 2014; Wikipedia, 2014).

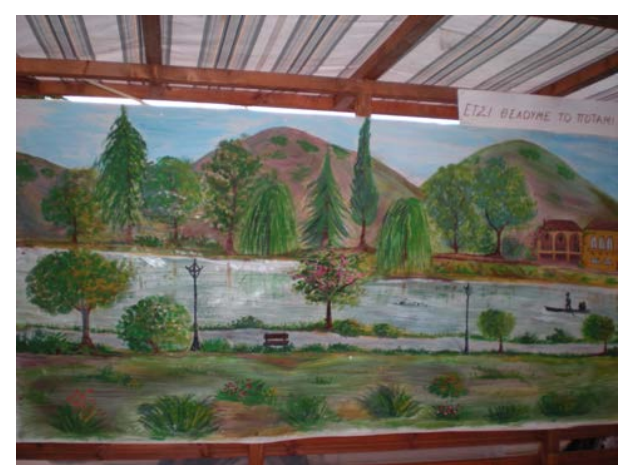

Figure S2. Detail of the final product of the workshop "How we want the riverside" (Red River Festival, 2009). 


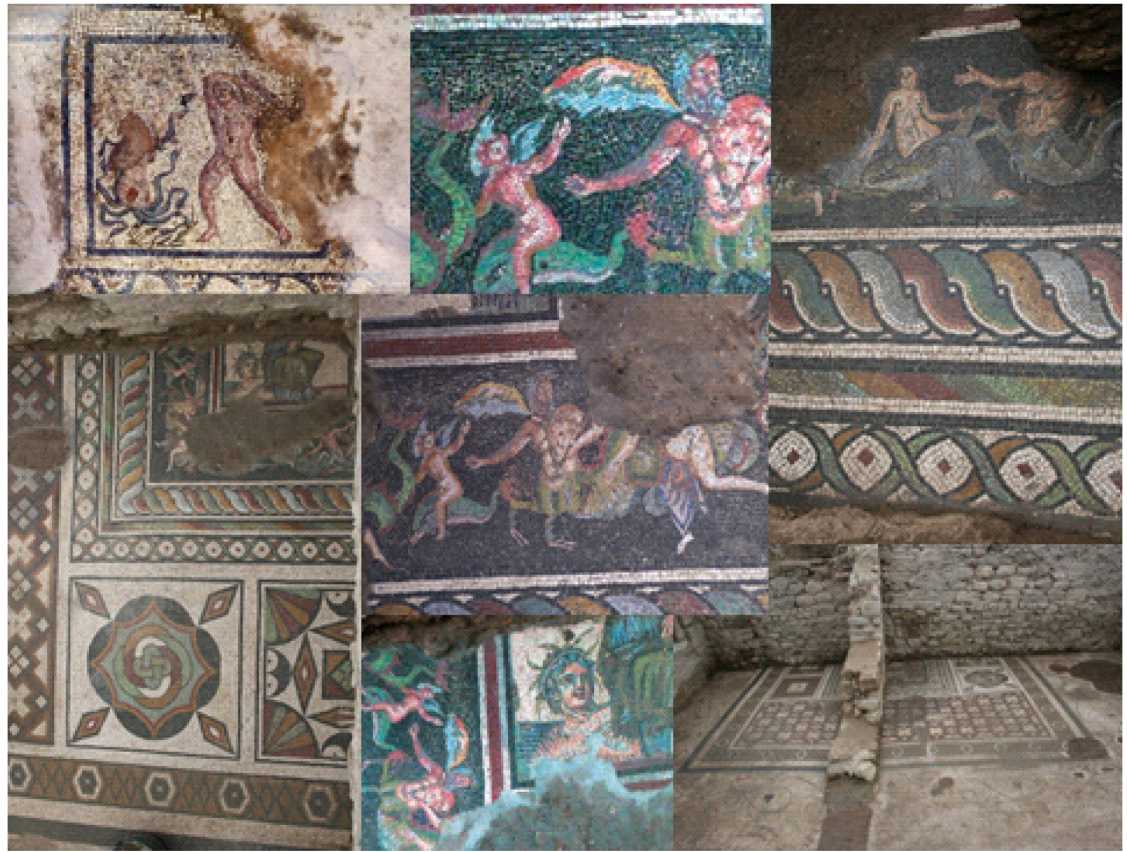

(a)

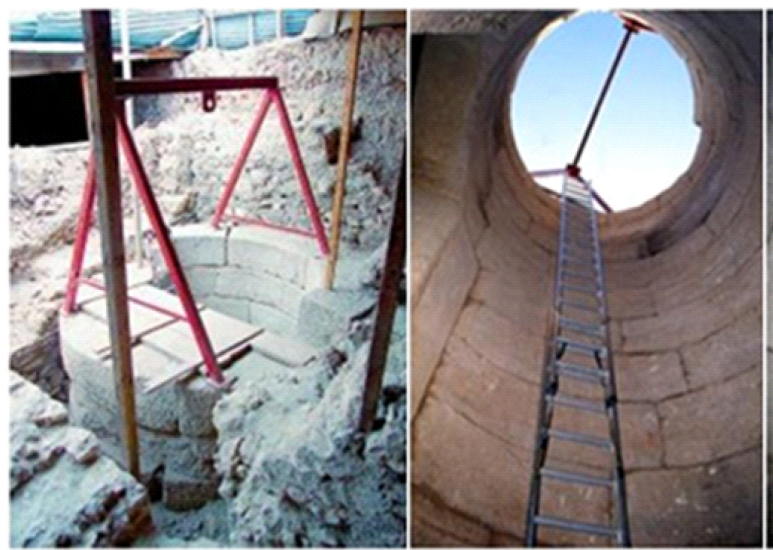

The well rim

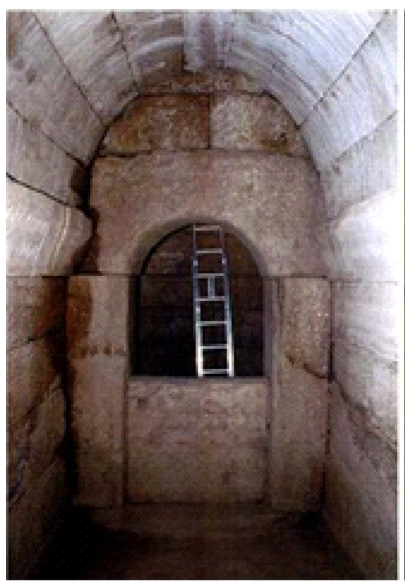

The chamber
The well masonry

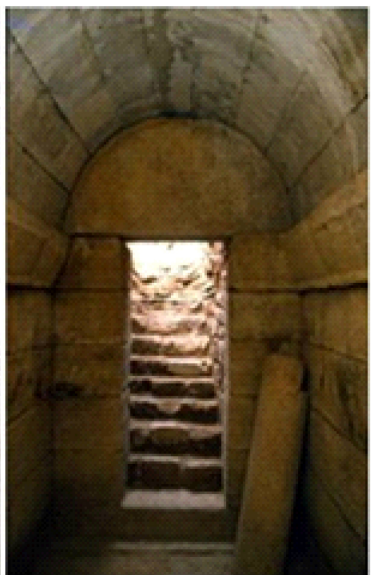

The chamber entrance

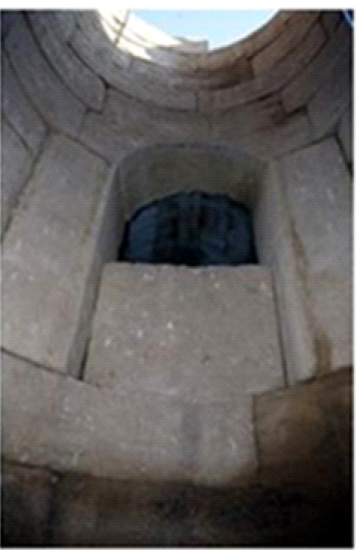

The opening for water

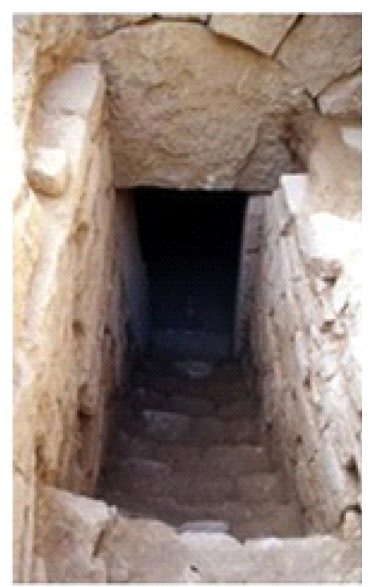

The stairs and entrance

(b)

Figure S3. Plotinopolis: (a) details of the Roman mosaic and (b) the complex of well and chamber (Municipality, 2014; Wikipedia, 2014). 


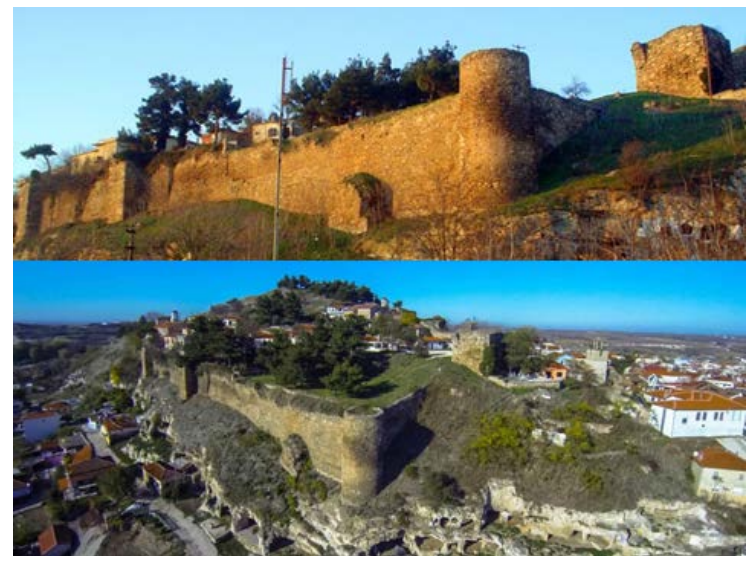

Figure S4. The castle walls (24 square or circular towers): the south-eastern side of the castle and the tower of princess (Municipality, 2014).

\section{References}

Municipality (2014). Municipality of Didymoteicho. https://www.didymoteicho.gr/en/istoriogrammi.html

T.E.T. (2014). Thracian Electronic Treasure. http://www.xanthi.ilsp.gr/thraki/tour/tour1.asp?geo=T43

Wikipedia. (2014). Didymoteicho. http://el.wikipedia.org/wiki/\%CE\%94\%CE\%B9\%CE\%B4\%CF\%85\%CE\%BC\%CF\%8C\% CF\%84\%CE\%B5\%CE\%B9\%CF\%87\%CE\%BF http://en.wikipedia.org/wiki/Didymoteicho

Submit or recommend next manuscript to SCIRP and we will provide best service for you:

Accepting pre-submission inquiries through Email, Facebook, LinkedIn, Twitter, etc. A wide selection of journals (inclusive of 9 subjects, more than 200 journals) Providing 24-hour high-quality service User-friendly online submission system Fair and swift peer-review system Efficient typesetting and proofreading procedure Display of the result of downloads and visits, as well as the number of cited articles Maximum dissemination of your research work

Submit your manuscript at: http://papersubmission.scirp.org/

Or contact cus@scirp.org 